\title{
Recent trends in measures to manage capital flows in emerging economies
}

\author{
Gurnain Kaur Pasricha ${ }^{1}$
}

\author{
31 January 2012
}

Bank of Canada

gpasricha@bankofcanada.ca

\begin{abstract}
This paper reviews recent trends in the imposition of capital flow management measures in emerging market economies (EMEs). We find that since the crisis, there has been a shift in the balance of new measures towards net capital inflow reducing measures. However, this is not driven primarily by an increase in inflow tightening measures (e.g. taxes on inflows), but rather by significantly slower inflow liberalization trends (i.e. existing capital controls remaining in place). In addition, there has been a compositional shift in net capital inflow reducing measures: outflow liberalizations were the predominant tools for reducing net capital inflows pre-crisis, but such measures have become less important post-crisis. Overall, the pre-crisis trend towards capital account openness has stalled. The use of capital flow management measures is motivated by macroeconomic as well as financial stability concerns. The IMF recently endorsed use of capital controls as "last resort" measures in macroeconomic management. We also find that by IMF criteria, capital flow measures have not been introduced as a last resort since 2004 alternative macroeconomic policies to deal with the surge in net capital inflows were available to the majority of countries. Moreover, most capital flow measures introduced by EMEs since 2004 are pure capital controls rather than currency based and/or prudential type measures, suggesting that they were not directly targeted to promote financial stability. However, since the crisis, there has been a small shift towards prudential-type measures.
\end{abstract}

\footnotetext{
1 I would like to thank Kristina Hess for outstanding research assistance, particularly for painstakingly collecting data on all the capital flow measures. My thanks also to Rose Chen who provided excellent research assistance and to Robert Lavigne, Rhys Mendes, Don Coletti and an anonymous referee for comments and encouragement. I would also like to acknowledge collaboration with Kun Mo on related work. The views expressed in this paper are personal and no responsibility for them should be attributed to the Bank of Canada.
} 
After a brief reversal during the recent financial crisis, private capital inflows to emerging market economies (EMEs) surged once again in 2010. Since capital inflow surges to emerging and developing economies are often followed by sudden stops, they can give rise to macroeconomic and financial stability concerns. Several EME policymakers have argued that in light of the risks posed by inflow surges, capital flow management measures (CFMs), which include capital controls, should be given recognition as a valid tool of macroeconomic and macroprudential management. Brazil became the first major EME to tighten inflow controls after the crisis.

However, CFMs can have global implications, going beyond the economy in which they are imposed. They can distort the global allocation of capital by shifting flows to other countries, and aid countries in maintaining competitiveness against their trading partners by resisting appreciation pressures. Adding to the debate on the appropriateness of capital controls, the IMF revised its long-standing opposition to such measures. It now suggests that capital controls may be used as a last resort, once primary macroeconomic responses have been exhausted. The IMF framework suggests that when primary macroeconomic responses have been exhausted, multilateral considerations need not prevent the use of capital controls.

The objective of this paper is to review the recent trends in CFMs in EMEs. In particular, this paper aims to:

1. Investigate whether the period since the 2008 financial crisis saw a large increase in 'net capital inflow restricting measures' on the capital account in emerging economies.

2. Examine whether the measures on the capital account were used as a last resort in macroeconomic management, i.e. were they restricted largely to emerging economies that were out of other macroeconomic management options?

3. Analyze the extent to which the EMEs are relying in capital controls to directly address financial stability concerns i.e. relying more on prudential type measures rather than "pure" capital controls. ${ }^{2}$

\section{Recent measures on the capital account in EMEs}

In this section, we describe our methodology for measuring capital flow measures and consider the recent trends in emerging economies with a focus on the measures introduced in 2010.

Our results indicate that since the crisis, there has been a shift in the balance of new measures towards net capital inflow reducing measures. A similar shift had occurred in 2007, the peak year during the last surge of net capital inflows to EMEs. What differentiates the 2010 episode is that the shift towards net capital inflow reducing measures is not primarily driven by an excessive increase in inflow tightening measures, but rather by a sharp slowdown in inflow liberalization trends.

\section{I.1 Methodology}

\footnotetext{
${ }^{2}$ See appendix A.3 for a discussion of the analytical distinctions between capital controls, capital flow measures and macroprudential measures.
}

Recent trends in measures to manage capital flows in emerging economies 
In order to analyze the evolution of capital flows policies in EMEs, we analyze all changes in regulation influencing capital account transactions. We refer to these measures as "Capital Flow Measures". The measures include:

- capital controls, i.e., measures on the capital account that differentiate based on residency of the transactor

- currency based measures, i.e., measures that differentiate based on currency of transaction

The measures include regulations applicable to the financial sector that are relevant for capital transactions. Note that CFMs as defined above would also include measures that aim to change the asset composition of capital flows, as long as such measures discriminate either by residency or by currency or both. An example of such a measure would be a tax on investment by foreign residents that taxes debt investments at a different (usually higher) rate than investments into equity market. It is also important to note here that our definition of CFMs is different from the IMF definition, which defines CFMs more broadly as all measures introduced with the objective of influencing capital flows. Thus defined, the CFM category can potentially include domestic measures, for example those that target an asset popular among non-residents but do not discriminate between residents and non-residents per se. ${ }^{3}$

We take a quantitative approach to analyzing policy measures, examining the number of policy measures on the capital account that EMEs have imposed since 2004. In doing this, we follow the IMF's Annual Report on Exchange Arrangements and Exchange Restrictions (AREAER), which carries out an analysis based on the number of changes. The number of measures per se does not allow us to judge the impact of the measures or to differentiate them by their degree of restrictiveness, which varies between countries. However, since most measures in the database are of relatively homogeneous magnitude, we think our approach, although imperfect, does provide useful information about the overall direction of policy, and about the attempts to liberalize or to close the capital account. ${ }^{4}$

Our sample consists of the 21 emerging markets that are in the MSCI Emerging Markets Index, and Argentina. ${ }^{5}$ The main source of data is the AREAER. ${ }^{6}$ The AREAER provides information on member countries' exchange arrangements, exchange and trade restrictions and capital transactions. We focus on the capital transactions section which includes regulations applicable to the financial sector that are relevant for capital transactions. The AREAER data is

\footnotetext{
${ }^{3}$ An example of such a measure would be the minimum holding period imposed by Indonesian Central Bank's certificates of deposit in 2010. Such measures are excluded from our analysis because we cannot be sure about the exhaustiveness of the list. On the other hand, our information on capital flow measures is expected to be reasonably exhaustive.

${ }^{4}$ If a major policy announcement includes several changes, each regarding a different category of transaction, each of these changes is counted individually. For example, on 14 March 2005, Brazil introduced three different changes - an elimination of the limit on investment in shares of the main company by employees of firms belonging to foreign groups; an elimination of the limit on remittances for outward FDI by non-financial private enterprises; and a removal of the authorization requirement for guarantees by non-financial judicial persons in credit operations for their foreign subsidiaries. Each of these changes is counted individually in our database.

${ }^{5}$ See data appendix A.4 for the list of countries.

${ }^{6}$ See appendix A.2 for more information on the measures, including a tabulation of all measures between January 2010 and January 2011, and their classification.
} 
supplemented with information on similar measures from central banks' websites, news sources and other research papers.

In order to better understand the direction of capital account policy, we group the measures into whether they would encourage or discourage Net Capital Inflows (NKI).

NKI are measured as the difference between capital inflows and outflows. In order to reduce NKI, a country may either tighten controls on inflows or ease controls on outflows. We therefore group all measures that constitute tightening of inflow controls or easing of outflow controls into the category of "NKI reducing measures" (Table 1). This category includes measures like taxes on inflows, unremunerated reserve requirements on inflows, reducing sectoral limits on FDI and on portfolio investments, etc. The category NKI reducing measures also includes measures that constitute an easing of controls on outflows, for example, increasing limits on portfolio investments abroad by pension funds and other FII, increasing annual limits on domestic individuals' investments abroad, easing interest rate caps on foreign borrowing, etc.

Analogously, the category "NKI increasing measures" includes all measures that constitute easing of inflow controls or tightening of outflow controls, as either type of measure would tend to increase NKI.

Table 1: Classification of capital flow measures into economic categories

\begin{tabular}{llcc}
\hline & & Inflow Controls & Outflow Controls \\
\hline 1. & NKI Reducing Measures & Tighten & Ease \\
2. & NKI Increasing Measures & Ease & Tighten \\
3. & Net NKI Restricting Measures $=$ NKI Reducing Measures - NKI Increasing Measures \\
\hline \hline
\end{tabular}

We further define "net NKI restricting measures" as the difference between NKI reducing measures and NKI increasing measures. Positive values of this summary measure reflect a policy bias towards reducing NKI. This last category embodies the overall effect of measures on net capital inflows, and may therefore have a macroeconomic interpretation. A higher number of net NKI restricting measures suggests that policymakers were more concerned with restricting NKI during that period, rather than increasing NKI.

\section{I.2. Are EMEs as a group restricting net capital inflows more now?}

Using the classifications described above, we look at the trends in net NKI restricting measures in EMEs. The 22 EMEs in our sample took about 518 measures on the capital account between January 1, 2004 and February 28, 2011. The number of net NKI restricting measures in EMEs as a group has indeed seen a rise in the post-recession period (Figure 1), such that the general sense 
that the policy stance in EMEs is tending towards reducing NKI seems correct. ${ }^{7}$ However, this rise in net NKI restricting measures is not new - a similar rise was seen pre-crisis in 2007, as the net capital inflows to EMEs peaked. The reversal in net capital inflows to EMEs during the crisis led to a cessation of net efforts to restrict such flows and these measures stayed low through 2009. With the resurgence of NKI to EMEs in 2010, the direction of policy tilted once again towards NKI reducing measures.

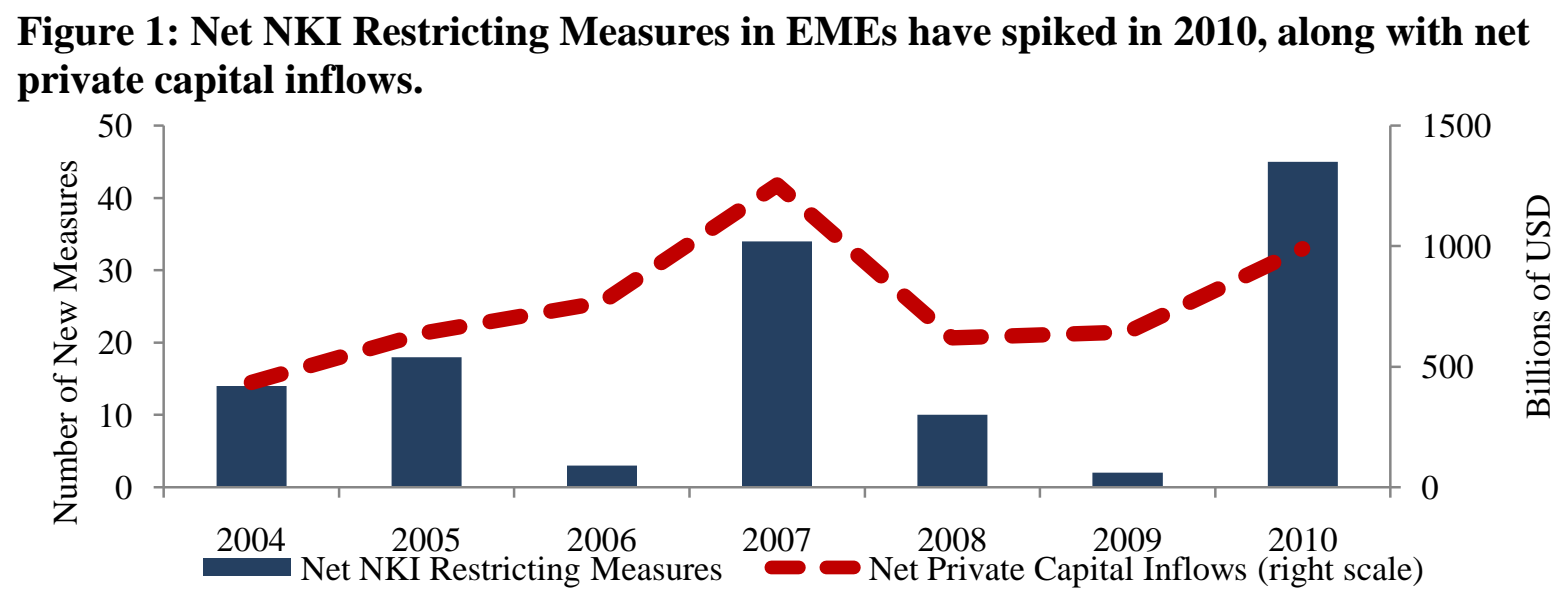

Note: IIF's classification of emerging markets is used for the net private capital inflows series, consisting of 9 countries in addition to the 21 used in the rest of this paper (excluding Taiwan). The additional countries include: Bulgaria, Romania, Ukraine, Ecuador, Venezuela, Lebanon, Nigeria, Saudi Arabia and UAE.

A breakdown of the data helps to provide some insights into the reasons behind the 2010 spike in net NKI restricting measures (Figures 2-4).

1. NKI reducing measures increased in 2010, to match pre-crisis levels (Figure 2). The blue bars in Figure 2 show that 2007 and 2008 were the peak years in terms of attempts to reduce net capital inflows. Therefore, the recent rise in NKI reducing measures from 2009 levels is not new - it is the continuation of a policy begun years before, but which was interrupted by the crisis. ${ }^{8}$ However, the crucial difference between these two periods is that in 2010, contrary to 2007-08, the rise in NKI reducing measures was not accompanied by a resumption of NKI increasing measures. During the 2007-08 surge in capital inflows to EMEs, these countries were liberalizing their capital accounts even as they were taking measures to restrict certain types of inflows and outflows. During 2010, however, EMEs seemed to be becoming more closed on the capital account, on the whole.

\footnotetext{
${ }^{7}$ The figure may be masking trends within different EMEs. The low values in 2008 and 2009, for example could just reflect the fact that different EMEs were moving in different directions in terms of reducing or increasing NKI.

${ }^{8}$ The overall trends described in the previous section could be influenced by one or more countries that were excessively active in managing their capital accounts through regulation. As a robustness check, we dropped the two countries (India and Peru) that took by far the most measures on the capital account during 2004-2010. While the number of measures in each category falls when both India and Peru are dropped, the pattern does not change. This indicates that our results do reflect the trends amongst emerging economies as a whole.
} 
2. The main force behind the shift toward net NKI restricting measures has been the decline in inflow liberalizations (Figure 3). Figure 3a shows that inflow easing measures were at their peak during 2007-08 but have dropped sharply in 2009-10. On the other hand, outflow tightening measures, which are another way of increasing NKI, have not been used much during our sample period. The decline in NKI increasing measures is therefore largely attributable to the large decline in easing of inflows. During the precrisis period of inflow surge, countries continued to make it easier for foreigners to invest in their country - a process that hasn't yet resumed post-crisis.

Figure 2: NKI reducing measures increased in 2010. NKI increasing measures have dropped since the crisis.

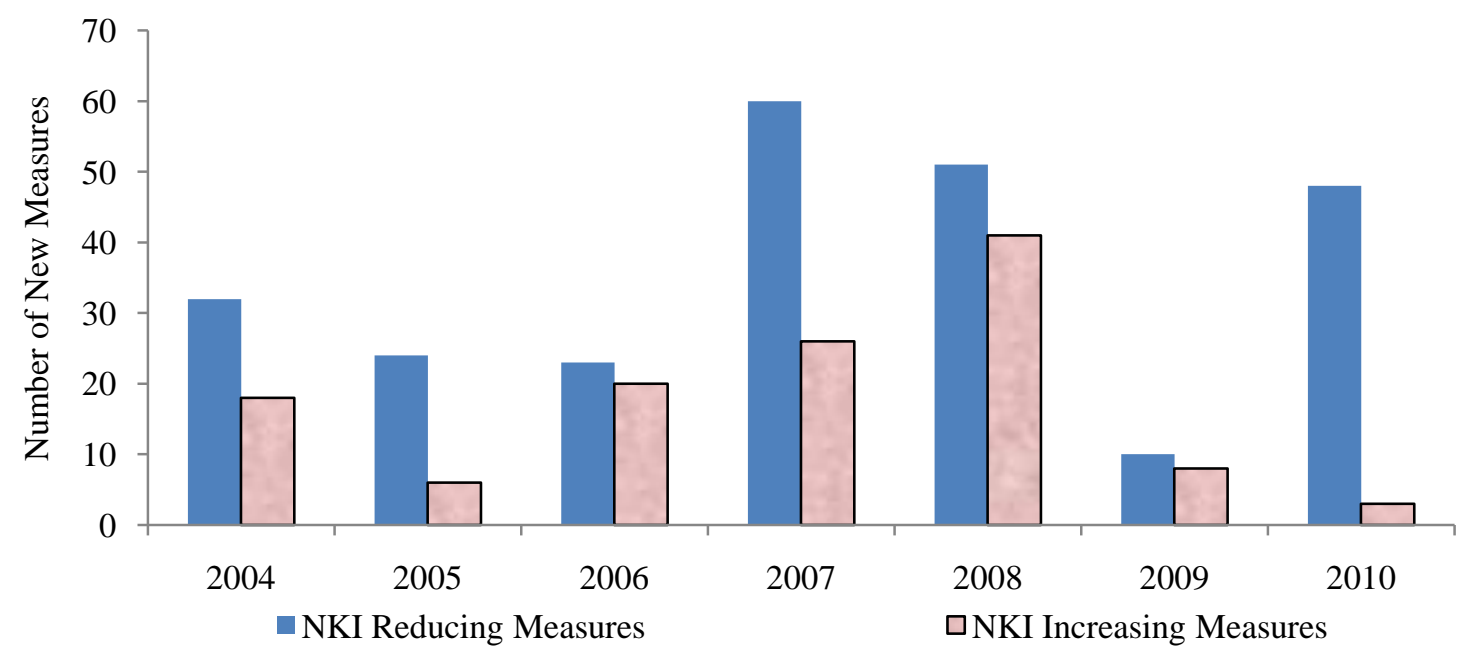

Figure 3a: Composition of NKI Increasing Measures. Inflow easing measures have dropped

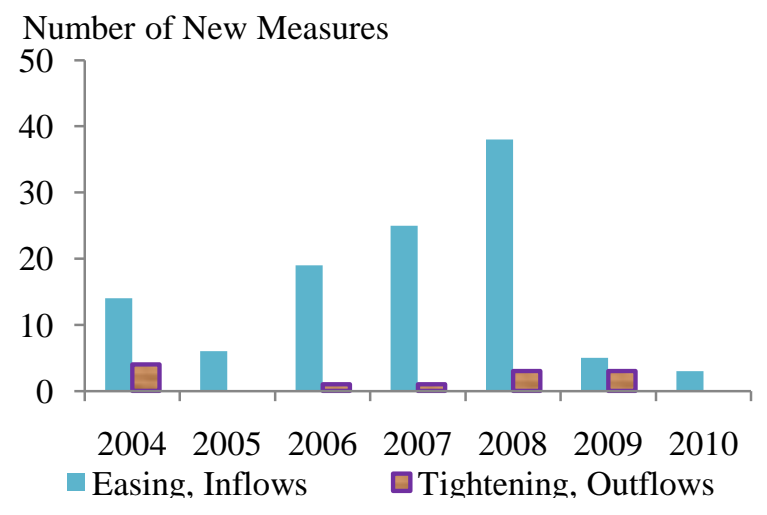

Figure 3b: Composition of NKI Reducing Measures. Outflow easings have reduced in importance

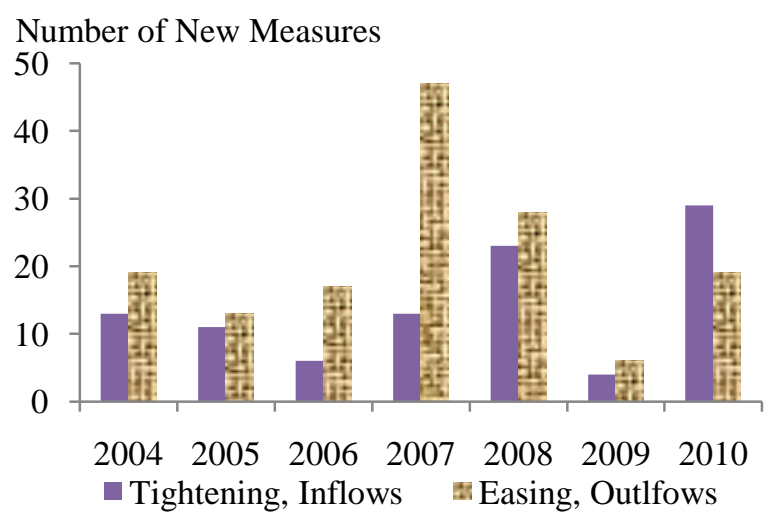

3. The regional trends parallel the overall trends. In Latin America, the number of net capital inflow reducing measures in 2010 recovered to their peak in 2008, but the net capital inflow increasing measures fell to almost zero (Figure 4a). In Asia, the NKI reducing measures in 2010 were not close to their 2007 peak, but the number of NKI increasing measures also fell to close to zero (Figure 4b). 
Figure 4a: Latin America

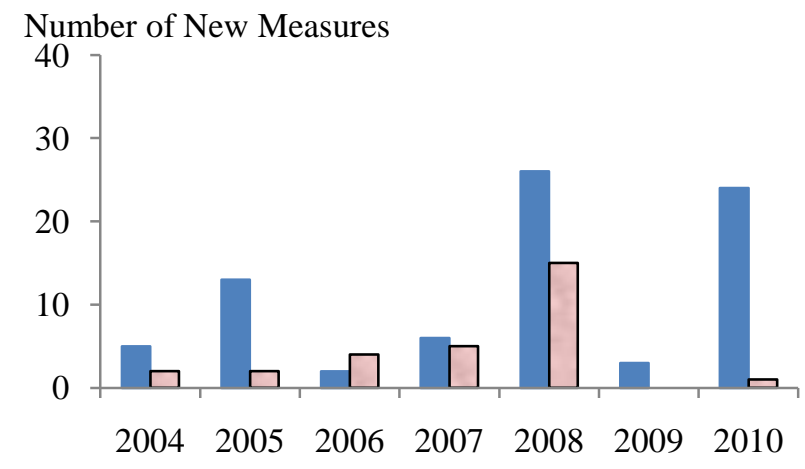

- NKI Reducing Measures $\square$ NKI Increasing Measures
Figure 4b: Asia

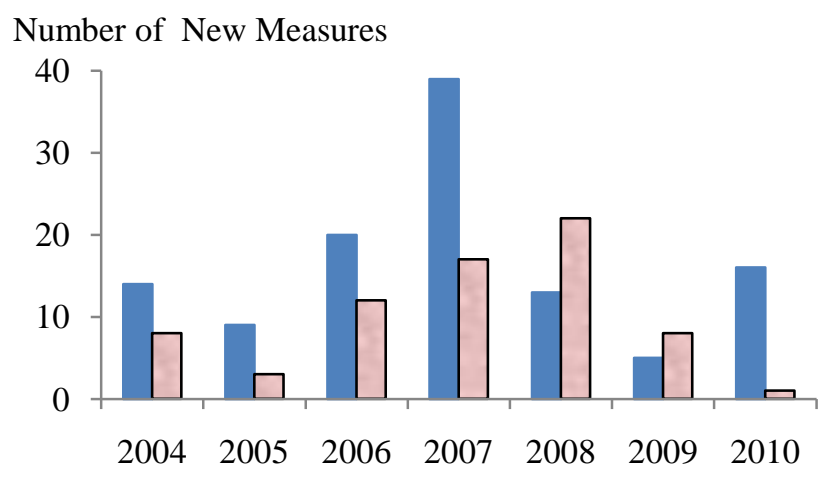

$\square$ NKI Reducing Measures $\square$ NKI Increasing Measures

Figure 5: The pre-crisis trend towards capital account liberalization has stalled

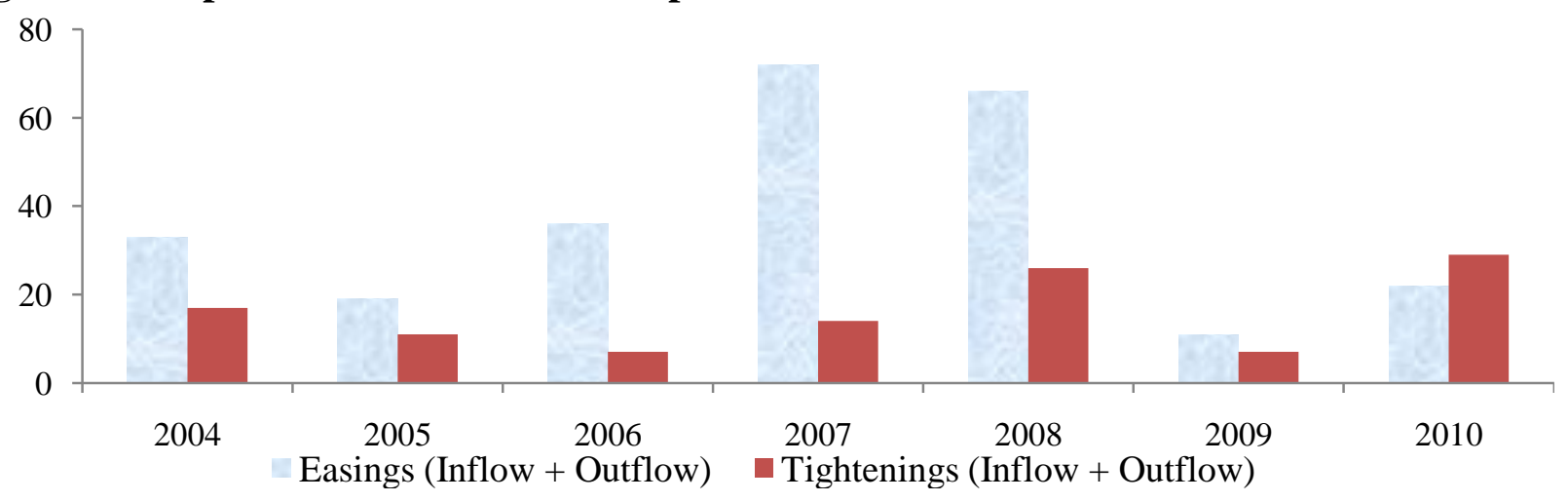

To summarize, we find a shift in net NKI restricting measures in EMEs as a group in 2010, similar to one seen in an earlier period of inflow surge, 2007. However, two crucial differences exist between the pre- and post-crisis periods: (i) the 2010 shift is more pronounced than the 2007 one, not because of a sharp rise in NKI reducing measures, but because of a fall in NKI increasing measures, in particular, a cessation of inflow liberalization trends; and (ii) there has been a compositional change within NKI reducing measures. Pre-crisis, the predominant instrument for reducing NKI was liberalization of outflows - but now it is relatively less important than inflow tightening measures.

Overall, the total number of liberalization measures (easing) on the capital account far exceeded the total number of tightening measures during the pre-crisis surge in capital inflows (figure 5). In 2010, the situation had reversed, with the liberalizations falling short of the tightening measures on the capital account. These trends indicate a pause, or at worst a small reversal, in the gradual process of global integration that the EMEs were involved in, pre-crisis. This stall in capital account liberalizations could make it more difficult to resolve global imbalances.

The decline in inflow liberalization may reflect political or economic realities. For example, putting a hold on liberalization may be easier from a legislative perspective than increasing restrictive measures. The crisis may also have diverted political and regulatory capital towards other issues. As far as the composition of NKI reducing measures is concerned, the reason for a 
relative decline may be that the financial crisis and the recent endorsement of capital controls by the IMF, made countries re-think the benefits of an open capital account. ${ }^{9}$

\section{I.3 How widespread is the increase in Net NKI Restricting measures in 2010?}

In this section, we take closer look at the measures introduced in 2010, by country. Brazil and Korea have been the most vocal in public discussions on capital controls. However, Table 1 shows that other emerging markets have also been active in taking net NKI restricting measures since the crisis. Brazil ranks $6^{\text {th }}$ amongst the 12 emerging markets that on the whole tried to restrict NKI in 2010, lagging behind Peru, Thailand, South Africa, Chile and Indonesia. However, the methods used to restrict NKI differed across countries. ${ }^{10}$ In Thailand, South Africa and Chile, net NKI reducing measures in 2010 consisted mostly of relaxations on outflows by residents rather than on new restrictions on inflows, thus becoming more open on the capital account. Therefore, among the larger EMEs, Brazil was accompanied by Indonesia and Taiwan in tightening inflow restrictions in 2010. Korea's measures consisted primarily of foreign currency based measures, measures restricting derivative exposures of financial institutions, or prudential type measures that could in principle influence both inflow and outflows.

To summarize, the trend towards net NKI restricting measures in 2010 was not driven by one or two country, but was more general among emerging markets.

Table 1: Number of restrictive measures, by country, in 2010

\begin{tabular}{lccc}
\hline Country & $\begin{array}{c}\text { Net NKI } \\
\text { Restricting }\end{array}$ & $\begin{array}{c}\text { Inflow } \\
\text { Tightenings }\end{array}$ & $\begin{array}{c}\text { Other Tightenings/ } \\
\text { Easings }\end{array}$ \\
\hline Peru & 16 & 14 & 5 \\
Thailand & 7 & 1 & 3 \\
South Africa & 6 & 1 & 0 \\
Chile & 4 & 0 & 0 \\
Indonesia & 4 & 4 & 0 \\
Brazil & 3 & 4 & 0 \\
Taiwan & 3 & 3 & 1 \\
Philippines & 2 & 0 & 2 \\
India & 1 & 1 & 0 \\
Korea & 0 & 0 & 6 \\
Turkey & 0 & 1 & 0 \\
China & -1 & 0 & 0 \\
\hline \hline
\end{tabular}

Note: Other Tightenings and Other Easings refer to measures that were not classified as pertaining to only inflow or to outflows. Most such measures are currency based measures. For details, see appendix A.2.

Having analyzed the broad trends in capital flow measures, in the next two sections, we turn to their use in macroeconomic management and promotion of financial stability.

\footnotetext{
${ }^{9}$ The IMF endorsement may have influenced 2010 data as IMF staff first endorsed capital controls in a February 2010 document, Ostry et. al. (2010).

${ }^{10}$ Note that the results in the previous section were robust to the exclusion of Peru and India.
} 


\section{Are capital flow measures being used as a last resort?}

To deal with the macroeconomic challenges posed by inflow surges, the IMF now recommends that the primary responses be macroeconomic policies, and that capital controls should be used as policies of last resort. ${ }^{11}$ The reason for recommending capital controls as last resort measures is that while inflow surges may pose some risks, international integration on the whole is beneficial for EMEs as it allows efficient risk sharing, optimal allocation of resources and fosters financial development. Moreover, using capital controls as substitutes for appropriate macroeconomic adjustment may be costly to the national economy, due to longer term misallocation of resources. This can lead to imbalances that have domestic and multilateral implications. Finally, capital controls are also recommended as measures of the last resort because the evidence on the effectiveness of capital controls in reducing the volume of flows is mixed. $^{12}$

In this section, we ask to what extent the CFMs have been used as last resorts according to the IMF's framework for determining "need to impose CFMs". We first describe the criteria and then apply it to EMEs for the years 2004 to $2010 .{ }^{13}$ Finally, we examine how often the imposition of CFMs would have been consistent with the IMF's proposed guidelines for their use. ${ }^{14}$

\section{II.1. IMF's criteria for determining "need to impose CFMs"}

The basic criterion for determining the "need to impose CFMs" is that other macroeconomic policy options have been exhausted. Accordingly, the IMF recommends the use of capital inflow measures in the face of an inflow surge if the following three conditions are jointly satisfied:

a) The exchange rate is not undervalued;

b) International reserves are in excess of adequate prudential levels or sterilization costs are too high; and

c) The economy is overheating, precluding monetary easing, and there is no scope to tighten fiscal policy.

Each of the three conditions for the "need to impose CFMs" (or its violation) represents a primary response option to an inflow surge. When the exchange rate is undervalued, the primary response option would be to allow it to appreciate; when the international reserves are inadequate, authorities may accumulate reserves; and when the economy is not overheating, the authorities may lower interest rates to reduce the return to inflows. The IMF uses numerical thresholds, as well as judgement based criteria, to evaluate whether each of these conditions have been met in $2010 .{ }^{15}$ One may debate the merits of the framework. For example, limiting exchange rate appreciation to a level consistent with long run fundamentals may limit the role of exchange rates in correcting imbalances. Moreover, while the framework recognizes the role of

\footnotetext{
${ }^{11} \operatorname{IMF}(2011 \mathrm{a})$.

${ }^{12}$ Ostry et. al. (2011)

${ }^{13}$ However, we do not have data on capital flows for Taiwan. Therefore this section contains analysis of only 21 countries, although in the section on capital controls, we include Taiwan.

${ }^{14}$ IMF (2011a).

${ }^{15}$ While the IMF criteria mention sterilization costs and fiscal policy, the numerical criteria they use does not evaluate countries on these.
}

Recent trends in measures to manage capital flows in emerging economies 
fiscal policy, the numerical criteria used in the paper do not include an assessment of the fiscal stance. For the purposes of this paper, we do not take a position on the validity of the framework or the criteria itself - we concern ourselves with its practical implications.

We follow closely the numerical criteria used by the IMF, described in detail in appendix A.1, to evaluate whether the CFMs are being used as a last resort. Briefly, we consider a country to be facing an inflow surge if the net capital inflows as a ratio of GDP are higher than recent trends or large in absolute value. Exchange rate undervaluations are based on CGER assessments where available; reserves are judged to be adequate if they cover short term external debt and current account deficit; and the economy is judged to be overheating if either the inflation rate is moderate or increasing or if the bank credit growth is high.

\section{II.2. The numerical criteria applied to EMEs since 2004}

Given the framework described above, in this section, we evaluate EMEs' macroeconomic policy options for each year since 2004. There are 34 country-year observations that satisfy the "need to impose CFMs" criteria, out of a total of 103 "surge" country-year pairs. Figure 6 provides the percentage of inflow tightening measures introduced in countries in years when the criteria for need to impose capital controls were/were not satisfied. The figure shows that the percentage of inflow tightening measures that could be justified as a last resort was low. Overall, the IMF conditions are satisfied in $23 \%$ of all country-year pairs and in $33 \%$ of the inflow surge cases, but the frequency varies by year. Therefore, most emerging markets had several primaryresponse macroeconomic policy options available to these in the years when they were facing inflow surges, suggesting that the capital flow measures that they imposed in these years were not taken as a "last resort". The picture is similar when one looks at net NKI restricting measures, instead of inflow tightening measures.

As expected, the results are sensitive to the numerical criteria used. As a robustness check, we changed the criteria for currency undervaluation. Up to now, we have used the Consultative Group on Exchange Rates (CGER) assessments as used in the IMF paper that introduced these criteria (except for 2004 and 2005 - see appendix A.1). If, following Rodrick (2008) we instead use adjusted PPP exchange rates as a measure of equilibrium exchange rate (adjusted by allowing for the fact that PPP does not hold in a predictable fashion - richer countries have more appreciated currencies) we find that the broad majority of countries facing a surge (85 percent) had room to allow their exchange rates to appreciate in 2004. That percentage fell to a strong majority (59 percent) in 2010. The proportion of countries that were out of other macroeconomic options and needed to impose CFMs using the alternative assessment of undervaluation was low in all years, peaking at 29 percent in 2008 and staying below 15 percent in other years. . ${ }^{16}$

However, this result is consistent with another possibility - that the capital flow measures were being imposed not with a macroeconomic stability objective but to target financial risks arising from the inflow surges. Since financial stability considerations continue to apply when there is a gross inflow surge, even if there is not a net inflow surge, we also compared the frequency of measures during years of non-FDI gross inflow surges and net capital inflow surges. The occurrence of non-FDI gross inflow surges is lower than the occurrence of net capital inflow

\footnotetext{
${ }^{16}$ However, as Table 1 shows, the 2010 split between measures that were/were not imposed as last resort would be more even if Peru is excluded.
}

Recent trends in measures to manage capital flows in emerging economies 
surges in the sample, so that less than half the total measures are taken in years in which there was a non-FDI gross inflow surge. ${ }^{17}$

Figure 6: Percentage of inflow tightening measures introduced when the IMF criteria for "need to impose CFMs" is/ is not satisfied

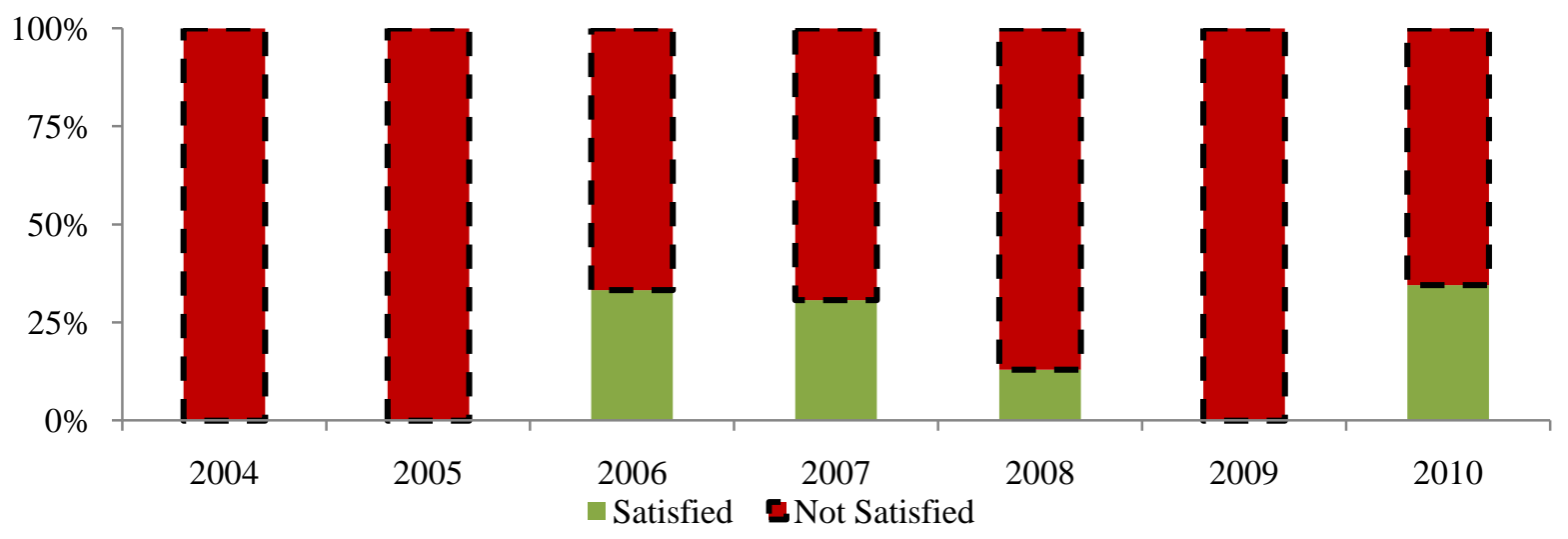

To further explore the use of capital controls to address financial stability concerns, in the next section, we examine the percentage of all measures taken that were prudential type measures.

\section{Are the EMEs relying more on prudential type instruments?}

Capital inflow surges may pose both macroeconomic and financial stability concerns. The IMF framework stresses the use of prudential tools, including currency based measures (defined below) as the primary policy responses to address financial stability risks arising from the inflow surges. Prudential tools include measures implemented at the level of individual financial institutions with the intention of strengthening their resilience to shocks. These instruments are typically in the toolkit of micro-prudential regulators and include provisioning requirements, leverage ratios, limits on currency mismatches, etc. In this section, we look at the composition of the capital flow measures undertaken by emerging markets and ask whether the currency based and prudential-type measures predominate. We classified the measures on the capital account into currency based or capital controls, as follows: ${ }^{18}$

a. Currency Based Measures: These are measures that discriminate based on currency, for example, between transactions denominated in domestic vs. foreign currency. These are further classified into:

i. Currency Based, Prudential Type (CBPT)

ii. Currency Based, Other Type (CBOT)

b. Capital Controls: these are measures that discriminate based on residency of the transactor. These are further classified into:

iii. Capital Controls, Prudential Type (CCPT)

iv. Capital Controls, Other Type (CCOT)

\footnotetext{
${ }^{17}$ Analogous to net capital inflow surges, non-FDI gross inflow surges are defined as years in which the non-FDI gross inflow exceeds its average of the last 5 years or is larger than 1.5 percent of GDP

${ }^{18}$ Further details on each of the categories are in appendix A.2.
} 
We find that the share of prudential-type measures has increased in recent years - but not by much (Figure 7). Most measures introduced since 2004 have been capital controls rather than currency based measures and the majority have been of the non-prudential type. However, the share of prudential-type measures - both capital controls and currency based has increased since the recent financial crisis. This may reflect the heightened focus on macroprudential management since the crisis. That being said, pure capital controls still comprised over 60 percent of measures. The increase in share of prudential-type and currency based measures is a positive trend, under the assumption that such measures are less distortive than residency based measures.

\section{Figure 7: Most measures were capital controls rather than currency based measures}

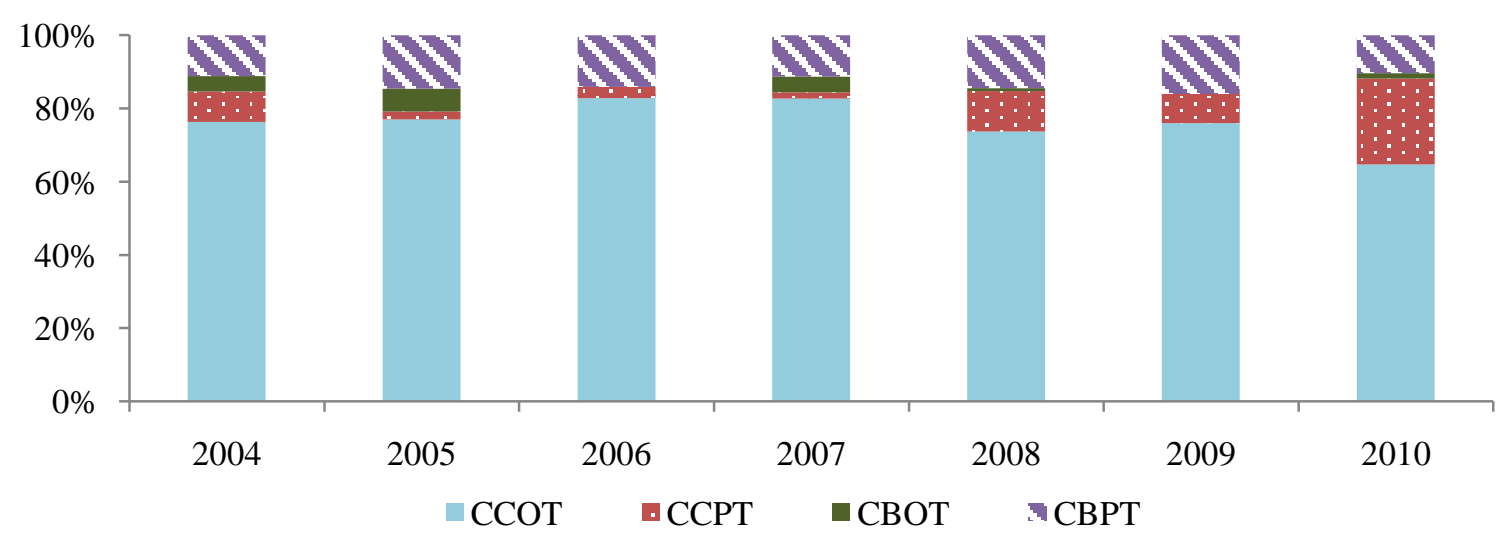

Notes: Abbreviations used are: CCPT - capital control, prudential type; CCOT - capital control, other; CBPT - currency-based measure, prudential type; CBOT - currency-based measure, other.

\section{Summary and Conclusions}

This paper examined the capital account measures taken by emerging markets for the years preceding the Great Recession and the period since. We find that since the crisis, there has been a shift in the balance of new measures towards net capital inflow reducing measures. This shift represents a stall in the pre-crisis liberalization trends. EMEs as a group were becoming more open on the capital account in the peak year of pre-crisis inflow surge, 2007, but this process ended with the crisis. This development has implications for the optimal allocation of global capital and for the resolution of global imbalances, but has not received much attention in policy circles.

We used numerical criteria broadly similar to that suggested by the IMF to evaluate whether the capital flow measures were being used as last resort by emerging economies. We found that in recent years, most EMEs have had at least one alternative macroeconomic option open to them even as they imposed CFMs. The measures were not being used as a last resort.

The paper also finds that most measures being imposed were pure capital controls measures, rather than prudential type measures, although since the recent financial crisis, there has been a small shift from non-prudential type measures to prudential type measures. This increase in the share of prudential-type and currency based measures is a positive trend, from a financial stability and efficiency point of view, under the assumption that prudential type measures are less distortive than pure capital controls. 
Further work is needed that would disentangle the macroeconomic and financial stability concerns by looking at different types of measures during more finely defined categories of inflow surges and by studying the associations between the macroeconomic situations and the use of each type of controls. Another extension of this work would evaluate the effectiveness of these measures.

\section{References}

Chinn, M. And Ito, H. (2008) "A New Measure of Financial Openness", Journal of Comparative Policy Analysis , 10(3), 309 - 322.

BIS (2008) "Addressing financial system pro-cyclicality: a possible framework", Note for the FSF Working Group on Market and Institutional Resilience.

Edwards, Sebastian (2001), "Capital Mobility and Economic Performance: Are Emerging Economies Different?” NBER Working Paper No. 8076.

FSB, IMF, BIS (2011), "Macroprudential policy tools and frameworks: Update to the G-20 Finance Ministers and Governors".

Glick, R., and M. Hutchison, 2001. "Banking and Currency Crises: How Common Are Twins?" in Financial Crises in Emerging Markets, ed. By Reuven R. Glick, R. Moreno, and M. M. Spiegel, New York: Cambridge University Press.

Grilli, V. and G. M. Milesi-Ferretti, 1995. "Economic Effects and Structural Determinants of Capital Controls," IMF Staff Papers 42(3) (September): 517 - 51.

IMF (2011a), "Recent Experiences in Managing Capital Inflows: Cross-Cutting Themes and Possible Framework”, IMF Policy Paper, Feb 12, 2011.

IMF (2011b) “Macroprudential policy: an Organizing Framework -Background paper”, IMF Policy Paper, March 14, 2011.

IMF (2010) “The Fund's Role Regarding Cross-Border Capital Flows”, IMF Policy Paper, November 15, 2010.

OECD (2009), Code of Liberalization of Capital Movements. (Paris: Organization for Economic Co-operation and Development).

Ostry, J. D., Ghosh, A. R., Habermeier, K., Chamon, M., Qureshi, M. S., and Reinhardt, D.B.S. (2010) "Capital Inflows: the Role of Controls", IMF Staff Position Note, 19 February 2010.

Ostry, J. D., Ghosh, A. R., Habermeier, K., Laeven, L., Chamon, M., Qureshi, M. S., and Kokenyne, A. (2011) "Managing Capital Inflows: What Tools to Use?", IMF Staff Discussion Note, April 5, 2011.

Reinhart, C. M., Reinhart, V. R. (2008), "Capital Flow Bonanzas: An Encompassing View of the Past and Present", NBER Working Paper No. 14321, September 2008. 
Rodrik, D. (2008), “The Real Exchange Rate and Economic Growth” in Douglas, W., Elmendorf, N., Mankiw G. and Summers, L. H., Eds, "Brookings Papers on Economic Activity", Fall 2008.

Quinn, Dennis (1997), "The Correlates of Change in International Financial Regulation," American Political Science Review 91(3): 531-551.

\section{Appendix}

\section{A.1. Numerical criteria for the IMF framework for assessing the "need to impose CFMs"}

We consider an economy as having faced an inflow surge during a given year if net capital inflows as a percentage of GDP during that year were:

i. higher than the average of the previous 5 years; or

ii. were higher than 1.5 percent of GDP ${ }^{19}$

For the year 2010, there is no data on net capital inflows for 4 countries - Egypt, India, Malaysia, Morocco. We assume these had a surge in this year.

The numerical targets used for the criteria for "need to impose CFMs" are closely follow IMF (2011a):

1. The economy is considered to be not overheating when both these criteria are met in a given year:

a. the year-on-year CPI inflation rate averaged less than 3 percent over the last two years, or less than 10 percent and declined from the average level of the preceding year

b. bank credit did not rise by more than 5 percent of GDP.

2. Reserves are judged to be adequate if the ratio of foreign exchange reserves (less gold) to the sum of short-term debt and the current account deficit (excluded if surplus) is above $100 \%$. If the current account was in surplus, the ratio is computed only as reserves/short term debt.

3. We use the IMF's CGER assessments of currency undervaluation. These assessments are available for emerging economies only since 2006 and are made twice a year - we consider a currency to be undervalued if the average estimate for misalignment was undervalued in both fall and spring assessments in that year. For the period before 2006, we use Rodrick (2008) currency undervaluation which classifies a currency as undervalued if its PPP real exchange rate is higher than 1 after taking into account the Balassa-Samuelson effect. As a robustness check, we use the PPP based assessments for

\footnotetext{
${ }^{19}$ Net capital inflows are measured by the sum of the capital and financial account balance, i.e. the net autonomous inflows. IMF (2011a) uses quarterly data on gross private capital inflows to identify inflow surges and classifies a quarter as seeing a surge if the gross inflows in that quarter significantly exceed their long run average (since 1990Q1) by one standard deviation or exceed 1.5 percent of annual GDP. However, the IMF does not apply the "need to impose CFMs" criteria only to countries facing a surge. There are 26 surge episodes using IMF definition of a surge in 2010, but the numerical criteria for "need to impose CFMs" is applied to 39 countries.
} 
the entire period. The PPP exchange rates are only available through 2009 - we use the 2009 assessment of undervaluation for 2010.

\section{A.2. Measures on the capital account and their classification}

The database includes information on the "capital transactions" category of the IMF's AREAER, supplemented by information on similar measures from central banks' websites, news sources and other research papers. The IMF's AREAER breaks down the broad category, capital transactions, as follows:

1. Controls on capital and money market instruments:

a. Controls on capital market securities: further classified into 'controls on shares or other securities of a participating nature' and 'banks or other debt securities'

b. Controls on money market instruments

c. Controls on collective investment schemes

2. Controls on derivatives and other instruments

3. Controls on Credit Operations:

a. Commercial Credits

b. Financial Credits

c. Guarantees, sureties and financial backup facilities

4. Controls on direct investment

5. Controls on liquidation of direct investment

6. Controls on real estate transactions

7. Controls on personal capital transactions

8. Provisions specific to the financial sector:

a. Provisions specific to commercial banks and other credit institutions, which includes open foreign exchange position limits and other provisions

b. Provisions specific to institutional investors

If a major policy announcement takes place and includes measures related to several categories above, each measure is classified in each category in which it belongs and is counted separately.

We classify the measures into the following categories:

1. Whether the measure (or change) impacts capital inflows (I) or outflows (O) or cannot be clearly identified as affecting only one of these categories (other) ${ }^{20}$

2. Whether the change represents an easing $(\mathrm{E})$ or tightening $(\mathrm{T})$ of policy or a neutral/ institutional change

In order to understand the direction of policy better, we group the measures into whether the measures would encourage or discourage Net Capital Inflows (NKI), i.e. the difference between inflows and outflows. This gives us the following categories:

3. NKI Reducing Measures: These are measures that represent tightening of inflows, easing of outflows or other tightening.

\footnotetext{
${ }^{20}$ Examples of the other measures that could not be classified as inflow or outflow measures include limits on net open foreign exchange positions of financial institutions, ban on use of foreign currency in special economic zones, restrictions on transactions that would constitute at once an inflow and outflow, for example use of external borrowing to invest abroad, etc.
} 
4. NKI Increasing Measures: These are measures that represent easing of inflows, tightening of outflows or other easing.

5. $\quad$ Net NKI Restricting Measures $=$ NKI Reducing Measures - NKI Increasing Measures

We also classify each of the measures on the following lines:

\section{Currency based or capital controls}

a. Currency Based Measures: These are measures that discriminate based on currency, for example, between transactions denominated in domestic vs. foreign currency.

i. Currency Based, Prudential Type (CBPT): These are prudential regulations specific to the financial sector measures that differentiate based on currency. They include limits on open foreign exchange (FX) positions, limits on banks' investments in FX assets, differential reserve requirements on liabilities in local currencies and $\mathrm{FX} .{ }^{21}$

ii. Currency Based, Other Type (CBOT): These are currency based measures that apply to the non-financial sector and do not discriminate between residents and non-residents. ${ }^{22}$ For example, on 1 April 2007, residents and non-residents were allowed to issue foreign currency bonds in Malaysia.

b. Capital Controls: these are measures that discriminate based on residency of the transactor.

iii. Capital Controls, Prudential Type (CCPT): These measures are applied to the financial sector only and are often similar to CBPT in design or impact. These include differential reserve requirements on non-resident deposits (which could have the same impact as a differential reserve requirement on foreign currency deposits if most foreign currency deposits are held by non-residents). Another example of this type of measures is the provisioning requirement of $2 \%$ that was imposed on Rouble and foreign currency obligations of credit institutions to non-resident banks, in Russia effective 1 August 2004.

iv. Capital Controls, Other Type (CCOT): This is the residual category of all measures on international transactions, payments and transfers related to capital account that discriminate based on residency of transactor.

7. The exchange rate regime of the countries adopting the policy changes. The information on exchange rate regimes is from the IMF's AREAER. Table A.1 provides descriptions of the IMF classifications.

\footnotetext{
${ }^{21}$ Basel Committee accepts limits on net open position of banks as prudential; however, many EMEs have imposed limits on long or short positions in FX or in one or more foreign currency. While these asymmetric open position limits can in principle be considered a capital control, we follow Ostry et. al. (2011) in classifying them as CBPT.

${ }^{22}$ However, these measures are often close to capital controls as while they do not discriminate between residents or non-residents on one side of the transaction, they often only apply to residents on the other side of the transaction. An example of this kind of regulation is in Malaysia on April 1, 2007, the limit on foreign currency borrowing by resident companies from licensed onshore banks and non-residents as well as through issuance of onshore foreign currency bonds was increased to 100 million Malaysian Ringgit or its equivalent in aggregate, and on a corporate group basis from the previous 50 million Ringgit. The proceeds were allowed to be used for domestic purposes or offshore investment.
} 
8. The monetary policy frameworks of the countries adopting the policy changes. The information on monetary policy frameworks is from the IMF's AREAER. Table A.1 provides descriptions of the IMF classifications.

9. Geographical regions.

Table A.2 classifies changes during 2010 and 2011 according to each of the above categories.

Table A.1: Description of IMF Classifications

\begin{tabular}{|c|c|}
\hline IMF Classification (Abbreviation) & Brief Description \\
\hline \multicolumn{2}{|l|}{ Exchange Rate Regimes } \\
\hline Free Floating $(\mathrm{FF})$ & $\begin{array}{l}\text { A largely market-determined exchange rate if there has been no } \\
\text { intervention over the preceding six months, with the exception of limited } \\
\text { intervention to address disorderly market conditions. }\end{array}$ \\
\hline Floating $(\mathrm{F})$ & $\begin{array}{l}\text { A largely market-determined exchange rate that is not classified as free } \\
\text { floating. }\end{array}$ \\
\hline Soft Peg (SP) & $\begin{array}{l}\text { Includes conventional pegged arrangements, pegged exchange rates within } \\
\text { horizontal bands, crawling pegs, stabilized arrangements, and crawl-like } \\
\text { arrangement. }\end{array}$ \\
\hline Other $(\mathrm{O})$ & $\begin{array}{l}\text { Any arrangement that does not fall into one of the categories described } \\
\text { above or hard pegs. }\end{array}$ \\
\hline \multicolumn{2}{|l|}{ Monetary Arrangements } \\
\hline Inflation-Targeting Framework (IT) & $\begin{array}{l}\text { This involves the public announcement of numerical targets for inflation, } \\
\text { with an institutional commitment by the monetary authorities to achieve } \\
\text { these targets, typically over a medium-term horizon. Additional key } \\
\text { features normally include increased communication with the public and } \\
\text { the markets about the plans and objectives of monetary policymakers and } \\
\text { increased accountability of the central bank for achieving its inflation } \\
\text { objectives. Monetary policy decisions are often guided by the deviation of } \\
\text { forecasts of future inflation from the announced inflation target, with the } \\
\text { inflation forecast acting (implicitly or explicitly) as the intermediate target } \\
\text { of monetary policy. }\end{array}$ \\
\hline Monetary Aggregate Target (MT) & $\begin{array}{l}\text { The monetary authority uses its instruments to achieve a target growth rate } \\
\text { for a monetary aggregate, such as reserve money, } \mathrm{M} 1 \text {, or } \mathrm{M} 2 \text {, and the } \\
\text { targeted aggregate becomes the nominal anchor or intermediate target of } \\
\text { monetary policy. }\end{array}$ \\
\hline Exchange Rate Anchor (XA) & $\begin{array}{l}\text { The monetary authority buys or sells foreign exchange to maintain the } \\
\text { exchange rate at its predetermined level or within a range. The exchange } \\
\text { rate thus serves as the nominal anchor or intermediate target of monetary } \\
\text { policy. These frameworks are associated with exchange rate arrangements } \\
\text { with no separate legal tender, currency board arrangements, pegs (or } \\
\text { stabilized arrangements) with or without bands, crawling pegs (or crawl- } \\
\text { like arrangements), and other managed arrangements. }\end{array}$ \\
\hline Other $(\mathrm{O})$ & $\begin{array}{l}\text { The country has no explicitly stated nominal anchor, but instead monitors } \\
\text { various indicators in conducting monetary policy. This category is also } \\
\text { used when no relevant information on the country is available. }\end{array}$ \\
\hline
\end{tabular}

Source: IMF AREAER 2009.

Notes for Monetary Arrangements: When a country classified as having both XA and IT, it was classified in this paper as XA. When a country was classified as having one of the listed categories and an IMF-supported program, it was classified in this paper as having the listed category. 
Table A.2: Recent Macroprudential Measures and Capital Controls in Emerging Markets

\begin{tabular}{|c|c|c|c|c|c|c|c|c|c|}
\hline Country & Year & $\begin{array}{l}\text { I/ } \\
\text { O }\end{array}$ & $\begin{array}{l}\mathbf{T} / \\
\mathbf{E}\end{array}$ & CC? & $\begin{array}{l}\mathbf{X} \\
\mathbf{R}\end{array}$ & $\begin{array}{l}\mathbf{M} \\
\mathbf{P}\end{array}$ & $\begin{array}{l}\mathrm{M} / \mathbf{P} \\
/ \mathrm{Q}\end{array}$ & $\mathbf{R}$ & Summary \\
\hline Brazil & 2010 & I & $\mathrm{T}$ & CCOT & $\mathrm{F}$ & IT & $\mathrm{P}$ & LA & $\begin{array}{l}\text { Announced a doubling of its financial operations tax or } \\
\text { Imposto sobre Operaçôes Financeiras (IOF) on the } \\
\text { foreign purchases of Brazilian bonds, from two to four } \\
\text { percent. Foreign direct and equity investments will not } \\
\text { see an increase }\end{array}$ \\
\hline Brazil & 2010 & I & $\mathrm{T}$ & CCOT & $\mathrm{F}$ & IT & $\mathrm{P}$ & LA & $\begin{array}{l}\text { Increased a tax it charges foreigners on investment in } \\
\text { fixed-income securities from } 4 \text { to } 6 \% \text { (also applies to } \\
\text { local equity funds, hedge funds and pension funds, } \\
\text { according to the Economic Times) }\end{array}$ \\
\hline Brazil & 2010 & I & $\mathrm{T}$ & CCOT & $\mathrm{F}$ & IT & $\mathrm{P}$ & LA & $\begin{array}{l}\text { Increased tax on margin deposits for derivative } \\
\text { contracts of non-residents }\end{array}$ \\
\hline Brazil & 2010 & I & $\mathrm{T}$ & CCOT & $\mathrm{F}$ & IT & Q & LA & $\begin{array}{l}\text { Brazil's government closed a loophole on a recently } \\
\text { raised tax on foreigners' investments in the country's } \\
\text { derivatives market. The new rules ban Brazilian } \\
\text { financial institutions, including banks and brokerages, } \\
\text { from renting, lending or swapping assets to foreigners } \\
\text { seeking to invest in the futures market, the Monetary } \\
\text { Council said in a statement last night. (Oct 21) }\end{array}$ \\
\hline Brazil & 2010 & I & $E$ & CCOT & $F$ & IT & $P$ & LA & $\begin{array}{l}\text { The government cut to } 2 \text { percent from } 6 \text { percent the so- } \\
\text { called IOF tax on foreign exchange transactions by } \\
\text { overseas investors into private equity funds, or FIPs, } \\
\text { and venture capital funds, according to a decree } \\
\text { published on Friday. }\end{array}$ \\
\hline Brazil & 2011 & I & $\mathrm{T}$ & CBPT & $\mathrm{F}$ & IT & $P$ & LA & $\begin{array}{l}\text { Starting April 4, Brazilian banks will need to deposit in } \\
\text { cash at the central bank } 60 \text { percent of their short } \\
\text { positions in U.S. dollars above } \$ 3 \text { billion or their } \\
\text { capital base, whichever is smaller. The reserves will not } \\
\text { earn interest. }\end{array}$ \\
\hline Chile & 2010 & $\mathrm{O}$ & $\mathrm{E}$ & CCOT & $\mathrm{FF}$ & IT & Q & LA & $\begin{array}{l}\text { Chile's central bank raised foreign investment limits for } \\
\text { pension funds from } 60 \% \text { to } 65 \% \text {, and set new limits on } \\
\text { foreign investment for each fund type. }\end{array}$ \\
\hline Chile & 2011 & $\mathrm{O}$ & $E$ & CCOT & $\mathrm{FF}$ & IT & $\mathrm{Q}$ & LA & $\begin{array}{l}\text { Chile's central bank raised foreign investment limits for } \\
\text { pension funds from } 65 \% \text { to } 70 \% \text {, and set new limits on } \\
\text { foreign investment for each fund type. }\end{array}$ \\
\hline Chile & 2011 & $\mathrm{O}$ & $\mathrm{E}$ & CCOT & $\mathrm{FF}$ & IT & $\mathrm{Q}$ & LA & $\begin{array}{l}\text { Chile's central bank raised foreign investment limits for } \\
\text { pension funds from } 70 \% \text { to } 75 \text {, and set new limits on } \\
\text { foreign investment for each fund type. }\end{array}$ \\
\hline Chile & 2011 & $\mathrm{O}$ & $E$ & CCOT & $\mathrm{FF}$ & IT & $\mathrm{Q}$ & LA & $\begin{array}{l}\text { Chile's central bank raised foreign investment limits for } \\
\text { pension funds from } 75 \% \text { to } 80 \% \text {, and set new limits on } \\
\text { foreign investment for each fund type. }\end{array}$ \\
\hline China & 2010 & $\mathrm{I}$ & $\mathrm{E}$ & CCOT & SP & $\begin{array}{l}\mathrm{X} \\
\mathrm{A}\end{array}$ & $\mathrm{Q}$ & $\mathrm{A}$ & $\begin{array}{l}\text { The People's Bank of China (PBOC) said on Aug } 17 \text { it } \\
\text { would let overseas financial institutions invest yuan } \\
\text { holdings in the nation's interbank bond market to } \\
\text { promote greater use of the yuan in global trade and } \\
\text { finance. }\end{array}$ \\
\hline India & 2010 & I & $\mathrm{T}$ & CCOT & $\mathrm{F}$ & $\mathrm{O}$ & $\mathrm{P}$ & $\mathrm{A}$ & $\begin{array}{l}\text { Interest rate cap on eligible external commercial } \\
\text { borrowing re-instated. }\end{array}$ \\
\hline India & 2011 & $\mathrm{O}$ & $\mathrm{E}$ & CCOT & $\mathrm{F}$ & $\mathrm{O}$ & $\mathrm{Q}$ & $\mathrm{A}$ & $\begin{array}{l}\text { the quantitative restriction on rupee-denominated debt } \\
\text { was doubled to } \$ 40 \text { bn with a focus on rupee- } \\
\text { denominated debt issued by infrastructure companies } \\
\text { (for FII investment in domestic corporate bonds) }\end{array}$ \\
\hline India & 2011 & I & $\mathrm{E}$ & CCOT & $\mathrm{F}$ & $\mathrm{O}$ & M & A & $\begin{array}{l}\text { permitted foreigners to invest in Indian mutual funds } \\
\text { without going through the process of FII registration }\end{array}$ \\
\hline Indonesia & 2010 & I & $\mathrm{T}$ & CBPT & $\mathrm{F}$ & IT & $\mathrm{P}$ & $\mathrm{A}$ & $\begin{array}{l}\text { hike of the foreign-currency deposit RR from } 1 \% \text { to } 5 \% \\
\text { in March }\end{array}$ \\
\hline
\end{tabular}




\begin{tabular}{|c|c|c|c|c|c|c|c|c|c|}
\hline Country & Year & I/ & $\begin{array}{l}\mathbf{T} / \\
\mathbf{E}\end{array}$ & CC? & $\begin{array}{l}\mathbf{X} \\
\mathbf{R}\end{array}$ & $\begin{array}{l}\mathbf{M} \\
\mathbf{P}\end{array}$ & $\begin{array}{l}\mathrm{M} / \mathrm{P} \\
/ \mathrm{Q}\end{array}$ & $\mathbf{R}$ & Summary \\
\hline Indonesia & 2010 & I & $\mathrm{T}$ & OMOT & $\mathrm{F}$ & IT & $\mathrm{Q}$ & $\mathrm{A}$ & $\begin{array}{l}\text { With effect from } 7 \text { July there will be a one-month } \\
\text { minimum holding period on Sertifikat Bank Indonesia } \\
\text { (SBIs). During the one-month period, ownership of } \\
\text { SBIs cannot be transferred. Issued by central bank, the } \\
\text { one-month SBIs are the favourite debt instruments } \\
\text { among foreign and local investors because of their high } \\
\text { yield (an interest rate of } 6.5 \% \text { in early June 2010) and } \\
\text { greater liquidity than other debt instruments. }\end{array}$ \\
\hline Indonesia & 2010 & I & $\mathrm{T}$ & CBPT & $\mathrm{F}$ & IT & $\mathrm{P}$ & A & $\begin{array}{l}\text { hike of the foreign-currency deposit RR from } 5 \% \text { i to } \\
8 \% \text { in June }\end{array}$ \\
\hline Indonesia & 2010 & I & $\mathrm{T}$ & CCPT & $\mathrm{F}$ & IT & $\mathrm{P}$ & $\mathrm{A}$ & $\begin{array}{l}\text { a } 30 \% \text { RR on vostro accounts (rupiah-denominated } \\
\text { transaction accounts held by nonresidents), to be } \\
\text { introduced Mar-11 (IMF report) or beginning end-Jan- } \\
11 \text { with 3-month transition (Reuters) }\end{array}$ \\
\hline Indonesia & 2010 & I & $\mathrm{T}$ & СCPT & $\mathrm{F}$ & IT & $\mathrm{Q}$ & $\mathrm{A}$ & $\begin{array}{l}\text { reimposition of a limit on short-term foreign borrowing } \\
\text { by banks to } 30 \% \text { of capital, effective March } 2011 \\
\text { (IMF) or end-Jan-11 (Jakarta Post) }\end{array}$ \\
\hline Korea & 2010 & & $\mathrm{~T}$ & CCOT & $\mathrm{FF}$ & IT & $\mathrm{Q}$ & $\mathrm{A}$ & $\begin{array}{l}\text { ceiling on domestic banks' FX derivatives contracts to } \\
\text { be no more than } 50 \% \text { and for foreign bank branches no } \\
\text { more than } 250 \% \text { (from } 300 \% \text { ) of their capital in } \\
\text { previous month }\end{array}$ \\
\hline Korea & 2010 & & $\mathrm{~T}$ & CCOT & $\mathrm{FF}$ & IT & Q & A & $\begin{array}{l}\text { Banks limited to providing } 100 \text { percent of underlying } \\
\text { transactions for forward contracts with exporters } \\
\text { (previously } 125 \text { percent). }\end{array}$ \\
\hline Korea & 2010 & & $\mathrm{~T}$ & CCOT & $\mathrm{FF}$ & IT & $\mathrm{Q}$ & $\mathrm{A}$ & $\begin{array}{l}\text { Bank loans in foreign currency to be restricted to } \\
\text { overseas uses only. Small and medium sized } \\
\text { manufacturers exempted. }\end{array}$ \\
\hline Korea & 2010 & & $\mathrm{~T}$ & CBPT & $\mathrm{FF}$ & IT & Q & $\mathrm{A}$ & $\begin{array}{l}\text { Local banks' FX loans and held-to-maturity securities } \\
\text { (equal to or more than one-year maturity) must be } \\
\text { covered by at least } 100 \text { percent of FX borrowing with } \\
\text { maturity of more than one year. }\end{array}$ \\
\hline Korea & 2010 & & $\mathrm{~T}$ & CBPT & FF & IT & $\mathrm{P}$ & $\mathrm{A}$ & $\begin{array}{l}\text { Announced plans to legislate a macroprudential } \\
\text { stability levy in H2 } 2011 \text { on non-deposit foreign } \\
\text { currency liabilities. The levy will fund provision of } \\
\text { forex liquidity when necessary. }\end{array}$ \\
\hline Korea & 2010 & & $\mathrm{~T}$ & CCOT & FF & IT & Q & $\mathrm{A}$ & $\begin{array}{l}\text { Limits on forex derivatives contracts of FIs tightened. } \\
\text { Contracts held by domestic banks limited to } 40 \% \text { of } \\
\text { their equity capital, from the current } 50 \% \text { regulation, } \\
\text { and those held by foreign banks to } 200 \% \text { from the } \\
\text { current ceiling of } 250 \% \text {. The official said that the } \\
\text { tightened restrictions are expected to go into effect } \\
\text { starting in March } 2011 \text {. }\end{array}$ \\
\hline Korea & 2011 & I & $\mathrm{T}$ & CCOT & FF & IT & $\mathrm{P}$ & $\mathrm{A}$ & $\begin{array}{l}\text { Inflows tax: } 20 \mathrm{bp} \text { levy on overseas debt maturing in } \\
\text { less than one year. Levy would initially be applied to } \\
\text { banks, though could be expanded to all financial } \\
\text { institutions if needed }\end{array}$ \\
\hline Peru & 2010 & I & $\mathrm{T}$ & CCPT & $\mathrm{F}$ & IT & $\mathrm{P}$ & LA & $\begin{array}{l}\text { Reserve requirements on non-deposit foreign liabilities } \\
\text { with maturity less than } 2 \text { years raised to } 40 \% \text { from } \\
35 \% \text {. }\end{array}$ \\
\hline Peru & 2010 & I & $\mathrm{T}$ & CCPT & $\mathrm{F}$ & IT & $\mathrm{P}$ & LA & $\begin{array}{l}\text { Marginal reserve requirements on local currency } \\
\text { deposits held by foreigners increased to } 35 \% \text { (from } \\
30 \% \text { ). }\end{array}$ \\
\hline Peru & 2010 & $\mathrm{O}$ & $\mathrm{E}$ & CCOT & $\mathrm{F}$ & IT & Q & LA & $\begin{array}{l}\text { Operating limit on pension funds' overseas investments } \\
\text { increased to } 28 \text { percent from } 26 \text { percent. }\end{array}$ \\
\hline Peru & 2010 & I & $\mathrm{T}$ & CCPT & $\mathrm{F}$ & IT & $\mathrm{P}$ & LA & $\begin{array}{l}\text { Marginal reserve requirements on local currency } \\
\text { deposits held by foreigners increased to } 50 \% \text { (from } \\
45 \% \text { ). }\end{array}$ \\
\hline Peru & 2010 & I & $\mathrm{T}$ & CCPT & $\mathrm{F}$ & IT & $\mathrm{P}$ & LA & $\begin{array}{l}\text { Increased reserve requirements on local currency } \\
\text { deposits held by foreigners to } 120 \%\end{array}$ \\
\hline Peru & 2010 & I & $\mathrm{T}$ & CCPT & $\mathrm{F}$ & IT & $\mathrm{P}$ & LA & $\begin{array}{l}\text { Increased reserve requirements on other foreign } \\
\text { liabilities with maturity less than } 2 \text { years to } 75 \% \text {. }\end{array}$ \\
\hline
\end{tabular}




\begin{tabular}{|c|c|c|c|c|c|c|c|c|c|}
\hline Country & Year & I/ & $\begin{array}{l}\mathbf{T} / \\
\mathbf{E}\end{array}$ & CC? & $\begin{array}{l}\mathbf{X} \\
\mathbf{R}\end{array}$ & $\begin{array}{l}\mathbf{M} \\
\mathbf{P}\end{array}$ & $\begin{array}{l}\mathrm{M} / \mathrm{P} \\
/ \mathrm{Q}\end{array}$ & $\mathbf{R}$ & Summary \\
\hline Peru & 2010 & I & $\mathrm{T}$ & СCPT & $\mathrm{F}$ & IT & $\mathrm{P}$ & LA & $\begin{array}{l}\text { Increased reserve requirements on local currency } \\
\text { deposits held by foreigners to } 120 \%\end{array}$ \\
\hline Peru & 2010 & I & $\mathrm{T}$ & ССРТ & $\mathrm{F}$ & IT & $\mathrm{P}$ & LA & $\begin{array}{l}\text { Increased reserve requirements on other foreign } \\
\text { liabilities with maturity less than } 2 \text { years to } 75 \% \text { (both } \\
\text { from } 50 \% \text { ). }\end{array}$ \\
\hline Peru & 2010 & $\mathrm{O}$ & $\mathrm{E}$ & CCOT & $\mathrm{F}$ & IT & $\mathrm{Q}$ & LA & $\begin{array}{l}\text { Operating limit on pension funds' overseas investments } \\
\text { increased to } 30 \text { percent this month from } 28 \text { percent } \\
\text { previously, the fourth increase this year. }\end{array}$ \\
\hline Peru & 2010 & & $\mathrm{~T}$ & CBPT & $\mathrm{F}$ & IT & $P$ & LA & $\begin{array}{l}\text { The minimum legal reserve mandate will rise to } 9 \\
\text { percent of lenders' loan portfolios from } 8.5 \text { percent, for } \\
\text { both soles and foreign currency, the bank said in an e- } \\
\text { mailed statement. The marginal requirement will rise to } \\
25 \text { percent from } 15 \text { percent for soles and to } 55 \text { percent } \\
\text { from } 50 \text { percent for foreign currency }\end{array}$ \\
\hline Peru & 2010 & $\mathrm{I}$ & $\mathrm{T}$ & ССРТ & $\mathrm{F}$ & IT & $\mathrm{P}$ & LA & $\begin{array}{l}\text { Reserve requirements on non-deposit foreign liabilities } \\
\text { with maturity less than } 2 \text { years raised to } 35 \% \text { from } 0 \% \text {. }\end{array}$ \\
\hline Peru & 2010 & I & $\mathrm{T}$ & CCPT & $\mathrm{F}$ & IT & $\mathrm{P}$ & LA & $\begin{array}{l}\text { Reserve requirements on non-deposit foreign liabilities } \\
\text { with maturity less than } 2 \text { years raised to } 50 \% \text { from } \\
40 \% \text {. }\end{array}$ \\
\hline Peru & 2010 & I & $\mathrm{T}$ & CCPT & $\mathrm{F}$ & IT & $\mathrm{P}$ & LA & $\begin{array}{l}\text { Marginal reserve requirements on local currency } \\
\text { deposits held by foreigners increased to } 45 \% \text { (from } \\
35 \% \text { ). }\end{array}$ \\
\hline Peru & 2010 & I & $\mathrm{T}$ & ССРТ & $\mathrm{F}$ & IT & $\mathrm{P}$ & LA & $\begin{array}{l}\text { Reserve requirements on non-deposit foreign liabilities } \\
\text { with maturity less than } 2 \text { years raised to } 65 \% \text { from } \\
50 \% \text {. }\end{array}$ \\
\hline Peru & 2010 & & $\mathrm{~T}$ & CBOT & $\mathrm{F}$ & IT & $\mathrm{Q}$ & LA & $\begin{array}{l}\text { imposed private pension funds' limit on trading FX at } \\
0.85 \% \text { of assets under management (for daily } \\
\text { transactions) and } 1.95 \% \text { (over 5-day period) }\end{array}$ \\
\hline Peru & 2010 & & $\mathrm{~T}$ & CBPT & $\mathrm{F}$ & IT & $\mathrm{Q}$ & LA & $\begin{array}{l}\text { Changed limits on banks' net FX position to } 75 \text { percent } \\
\text { for long position (from } 100 \text { percent) and } 15 \text { percent for } \\
\text { short position (from } 10 \text { percent) }\end{array}$ \\
\hline Peru & 2010 & & $\mathrm{~T}$ & CBPT & $\mathrm{F}$ & IT & $\mathrm{Q}$ & LA & $\begin{array}{l}\text { implemented additional capital requirements for FX } \\
\text { credit risk exposure }\end{array}$ \\
\hline Peru & 2010 & I & $\mathrm{T}$ & CCOT & $\mathrm{F}$ & IT & $\mathrm{P}$ & LA & $\begin{array}{l}\text { Increased fee on foreign purchases of central bank } \\
\text { liquidity draining instruments to } 400 \mathrm{bps} \text { (from } 200 \mathrm{bp} \text { ) }\end{array}$ \\
\hline Peru & 2010 & $\mathrm{I}$ & $\mathrm{T}$ & CCOT & $\mathrm{F}$ & IT & $P$ & LA & $\begin{array}{l}\text { Imposed } 30 \text { percent capital gains tax on nonresidents' } \\
\text { investments in the stock market for transactions } \\
\text { through Peruvian broker and at } 5 \text { percent for } \\
\text { transactions through a nonresident broker. }\end{array}$ \\
\hline Peru & 2010 & & $\mathrm{~T}$ & CCOT & $\mathrm{F}$ & IT & $\mathrm{P}$ & LA & $\begin{array}{l}30 \% \text { tax on foreign investor gains from PEN- } \\
\text { denominated futures maturing within } 60 \text { days }\end{array}$ \\
\hline Peru & 2010 & I & $\mathrm{T}$ & ССРТ & $\mathrm{F}$ & IT & $\mathrm{P}$ & LA & $\begin{array}{l}\text { Marginal reserve requirements on local currency } \\
\text { deposits held by foreigners increased to } 65 \% \text { (from } \\
50 \% \text { ). }\end{array}$ \\
\hline Peru & 2011 & & $\mathrm{~T}$ & CCOT & $\mathrm{F}$ & IT & Q & LA & $\begin{array}{l}\text { The director of the Office of the Superintendent of } \\
\text { Banking, Insurance and Private Pension Funds, Felipe } \\
\text { Tam, signed a legal regulation limiting the forward } \\
\text { holdings to a net } 40 \% \text { of a company's assets, or } 400 \\
\text { million soles ( } \$ 144 \text { million), whichever is greater. } \\
\text { Companies will have up to } 90 \text { days to conform with the } \\
\text { new regulation. }\end{array}$ \\
\hline Peru & 2011 & I & $\mathrm{E}$ & CBPT & $\mathrm{F}$ & IT & $\mathrm{P}$ & LA & $\begin{array}{l}\text { Reduced reserve requirements on foreign currency } \\
\text { liabilities to } 60 \text { percent }\end{array}$ \\
\hline Peru & 2011 & I & $\mathrm{T}$ & CBPT & $\mathrm{F}$ & IT & $\mathrm{P}$ & LA & $\begin{array}{l}\text { The central Bank increased average reserve } \\
\text { requirements on both domestic and foreign currency } \\
\text { loans by } 25 \text { basis points from their initial levels of } 11.8 \\
\text { percent and } 35.6 \text { percent, respectively }\end{array}$ \\
\hline
\end{tabular}




\begin{tabular}{|c|c|c|c|c|c|c|c|c|c|}
\hline Country & Year & I/ & $\begin{array}{l}\mathbf{T} / \\
\mathbf{E}\end{array}$ & CC? & $\begin{array}{l}\mathbf{X} \\
\mathbf{R}\end{array}$ & $\begin{array}{l}\mathbf{M} \\
\mathbf{P}\end{array}$ & $\begin{array}{l}\mathrm{M} / \mathrm{P} \\
/ \mathrm{Q}\end{array}$ & $\mathbf{R}$ & Summary \\
\hline Philippines & 2010 & & $E$ & CCOT & $\mathrm{F}$ & IT & $\mathrm{M}$ & $\mathrm{A}$ & $\begin{array}{l}\text { Allow prepayment of BSP-registered foreign/foreign } \\
\text { currency loans of the private sector to be funded with } \\
\text { FX from AABs/AAB-forex corps without prior BSP } \\
\text { approval, subject to presentation of supporting } \\
\text { documents }\end{array}$ \\
\hline Philippines & 2010 & & $\mathrm{E}$ & CCOT & $\mathrm{F}$ & IT & Q & A & $\begin{array}{l}\text { Allow registering banks to act on requests by foreign } \\
\text { investors for conversion to FX and outward remittance } \\
\text { of peso funds not to exceed the FX brought in less the } \\
\text { amount used for investments actually made in the } \\
\text { country }\end{array}$ \\
\hline Philippines & 2010 & $\mathrm{O}$ & $E$ & CCOT & $\mathrm{F}$ & IT & $\mathrm{Q}$ & $\mathrm{A}$ & $\begin{array}{l}\text { Increase in the present ceiling of US\$30 million to } \\
\text { US } \$ 60 \text { million per investor per year, of the amount that } \\
\text { residents may purchase from authorized agent banks } \\
\text { for outward investments and/or investments in ROPs } \\
\text { and other Philippine debt papers issued offshore, } \\
\text { including peso-denominated instruments to be settled in } \\
\text { FX }\end{array}$ \\
\hline Philippines & 2010 & $\mathrm{O}$ & $E$ & CCOT & $\mathrm{F}$ & IT & $\mathrm{M}$ & A & $\begin{array}{l}\text { Lift the registration requirement for outward } \\
\text { investments in excess of the USD } 60 \text { million limit and } \\
\text { replace this with reporting to BSP }\end{array}$ \\
\hline $\begin{array}{l}\text { South } \\
\text { Africa }\end{array}$ & 2010 & $\mathrm{I}$ & $\mathrm{T}$ & CCOT & $\mathrm{F}$ & IT & Q & Af & $\begin{array}{l}\text { As of } 1 \text { March } 2010 \text { South African banks will be able } \\
\text { to acquire direct and indirect foreign exposure up to } \\
25 \% \text { of their total liabilities (excluding equity), } \\
\text { covering all foreign exposure but excluding FDI. The } \\
\text { initial limit of } 40 \% \text { has been adjusted downwards in } \\
\text { light of recent international developments }\end{array}$ \\
\hline $\begin{array}{l}\text { South } \\
\text { Africa }\end{array}$ & 2010 & $\mathrm{O}$ & $E$ & CCOT & $\mathrm{F}$ & IT & $\mathrm{M}$ & Af & $\begin{array}{l}\text { Authorities allowed qualifying international } \\
\text { headquarter companies to raise and deploy capital } \\
\text { offshore without exchange control approval }\end{array}$ \\
\hline $\begin{array}{l}\text { South } \\
\text { Africa }\end{array}$ & 2010 & $\mathrm{O}$ & $E$ & CCOT & $F$ & IT & $\mathrm{P}$ & Af & $\begin{array}{l}\text { Authorities eliminated the } 10 \text { percent levy on the } \\
\text { capital that South Africans could transfer upon } \\
\text { emigration. }\end{array}$ \\
\hline $\begin{array}{l}\text { South } \\
\text { Africa }\end{array}$ & 2010 & $\mathrm{O}$ & $E$ & CCOT & $\mathrm{F}$ & IT & Q & Af & $\begin{array}{l}\text { Authorities raised the limit on individuals investment } \\
\text { offshore to } \mathrm{R} 4 \text { million per year from } \mathrm{R} 4 \text { million in a } \\
\text { lifetime. }\end{array}$ \\
\hline $\begin{array}{l}\text { South } \\
\text { Africa }\end{array}$ & 2010 & $\mathrm{O}$ & $\mathrm{E}$ & CCOT & $\mathrm{F}$ & IT & Q & Af & $\begin{array}{l}\text { Authorities raised the single discretionary allowance to } \\
\mathrm{R} 1 \text { million from } \mathrm{R} 750,000 \text {. }\end{array}$ \\
\hline $\begin{array}{l}\text { South } \\
\text { Africa }\end{array}$ & 2010 & $\mathrm{O}$ & $\mathrm{E}$ & CCOT & $\mathrm{F}$ & IT & Q & Af & $\begin{array}{l}\text { Increased limits to allow different types of institutions } \\
\text { to take between } 25 \text { and } 35 \text { percent of assets abroad. }\end{array}$ \\
\hline Taiwan & 2010 & I & $\mathrm{T}$ & CCPT & & & $\mathrm{P}$ & $\mathrm{A}$ & $\begin{array}{l}\text { A reserve requirement ratio of } 25 \text { percent will apply to } \\
\text { existing local currency passbook deposits held by } \\
\text { foreigners, while } 90 \text { percent will be imposed on any net } \\
\text { increase in such deposits after Dec. } 30\end{array}$ \\
\hline Taiwan & 2010 & I & $\mathrm{T}$ & CCPT & & & $\mathrm{P}$ & A & $\begin{array}{l}\text { Monetary authority won't pay lenders interest from Jan. } \\
1 \text { on reserves held for deposits from foreigners. It } \\
\text { currently pays interest on } 55 \text { percent of the reserves. }\end{array}$ \\
\hline Taiwan & 2010 & & $\mathrm{~T}$ & CCOT & & & $\mathrm{Q}$ & $\mathrm{A}$ & $\begin{array}{l}\text { Trading in NDFs capped at one-fifth of a bank's total } \\
\text { forex trading }\end{array}$ \\
\hline Taiwan & 2010 & I & $\mathrm{T}$ & CCOT & & & Q & $\mathrm{A}$ & $\begin{array}{l}\text { offshore funds restricted to investing no more than } 30 \\
\text { percent of their portfolios into local government debt } \\
\text { and money-market products. }\end{array}$ \\
\hline Thailand & 2010 & & $E$ & CCOT & $\mathrm{F}$ & IT & Q & $\bar{A}$ & $\begin{array}{l}\text { Relaxed regulations regarding corporate treasury } \\
\text { centres in Thailand to allow companies in Thailand to } \\
\text { have more flexibility in managing their foreign } \\
\text { currencies. Allowed a company to conduct treasury } \\
\text { center B/S and to transfer foreign exchange between } \\
\text { the centre and its affiliate companies in Thailand. }\end{array}$ \\
\hline Thailand & 2010 & & $E$ & CCOT & $\mathrm{F}$ & IT & $\mathrm{Q}$ & $\mathrm{A}$ & $\begin{array}{l}\text { Relaxed other regulations for Thai residents which } \\
\text { include: raising outstanding balance limits on foreign } \\
\text { currency deposit accounts deposited with funds } \\
\text { exchanged from commercial banks }\end{array}$ \\
\hline
\end{tabular}

Recent trends in measures to manage capital flows in emerging economies 


\begin{tabular}{|c|c|c|c|c|c|c|c|c|c|}
\hline Country & Year & I/ & $\begin{array}{l}\mathbf{T} / \\
\mathbf{E}\end{array}$ & CC? & $\begin{array}{l}\mathbf{X} \\
\mathbf{R}\end{array}$ & $\begin{array}{l}\mathbf{M} \\
\mathbf{P}\end{array}$ & $\begin{array}{l}\mathrm{M} / \mathrm{P} \\
/ \mathrm{Q}\end{array}$ & $\mathbf{R}$ & Summary \\
\hline Thailand & 2010 & $\mathrm{O}$ & $E$ & CCOT & $\mathrm{F}$ & IT & $\mathrm{Q}$ & A & $\begin{array}{l}\text { Permitted Thai companies to invest abroad in the form } \\
\text { of direct investment or lend to affiliated companies up } \\
\text { to USD } 50 \text { million per year }\end{array}$ \\
\hline Thailand & 2010 & $\mathrm{O}$ & $\mathrm{E}$ & CCOT & $\mathrm{F}$ & IT & Q & A & $\begin{array}{l}\text { Relaxed other regulations for Thai residents which } \\
\text { include: increasing amount limit for purchase of } \\
\text { immovable properties abroad }\end{array}$ \\
\hline Thailand & 2010 & & $E$ & CCOT & $\mathrm{F}$ & IT & $\mathrm{Q}$ & A & $\begin{array}{l}\text { Relaxed other regulations for Thai residents which } \\
\text { include: relaxing regulations on repatriation by raising } \\
\text { the threshold amount above which foreign currency } \\
\text { proceeds are required to be brought into Thailand, as } \\
\text { well as relaxing the related reporting requirement }\end{array}$ \\
\hline Thailand & 2010 & $\mathrm{I}$ & $\mathrm{T}$ & CCOT & $\mathrm{F}$ & IT & $\mathrm{P}$ & $\mathrm{A}$ & $\begin{array}{l}\text { a withholding tax of } 15 \% \text { will be imposed on interest } \\
\text { income and capital gains receivable by non-resident } \\
\text { corporate and individual investors on bonds issued by } \\
\text { the government, state enterprises and the Bank of } \\
\text { Thailand }\end{array}$ \\
\hline Thailand & 2010 & $\mathrm{O}$ & $E$ & CCOT & $\mathrm{F}$ & IT & Q & A & $\begin{array}{l}\text { Raised limits on foreign asset accumulation by } \\
\text { residents, including outward FDI }\end{array}$ \\
\hline Thailand & 2010 & $\mathrm{O}$ & $E$ & CCOT & $\mathrm{F}$ & IT & Q & A & Removed limit on direct overseas investment. \\
\hline Thailand & 2010 & $\mathrm{O}$ & $\mathrm{E}$ & CCOT & $\mathrm{F}$ & IT & Q & A & $\begin{array}{l}\text { Relaxed restrictions on lending by Thai firms to } \\
\text { nonresident borrowers. }\end{array}$ \\
\hline Thailand & 2010 & $\mathrm{O}$ & $\mathrm{E}$ & CCOT & $\mathrm{F}$ & IT & Q & A & Raised cap on offshore property purchase. \\
\hline Turkey & 2010 & & $\mathrm{~T}$ & & $\mathrm{~F}$ & IT & $\mathrm{P}$ & $\mathrm{E}$ & raised banks' lira reserve requirements to 6 from $5.5 \%$ \\
\hline Turkey & 2010 & & $\mathrm{~T}$ & & $\mathrm{~F}$ & IT & $\mathrm{P}$ & $\mathrm{E}$ & $\begin{array}{l}\text { Lira reserve requirement ratio (RRR) differentiated } \\
\text { across maturities, ranging from } 5 \text { percent for deposits } \\
\text { with maturity of at least one year to } 8 \text { percent for up to } \\
\text { one month. FX RRR kept at pre-crisis level of } 11 \\
\text { percent. Remuneration of reserve requirements halted }\end{array}$ \\
\hline Turkey & 2010 & I & $E$ & CCOT & $\mathrm{F}$ & IT & $\mathrm{P}$ & $E$ & $\begin{array}{l}\text { Turkey on Thursday announced reductions in the } \\
\text { withholding tax rate on bonds issued abroad by Turkish } \\
\text { firms with a maturity of more than three years, in a bid } \\
\text { to encourage long term investment. Previously the } \\
\text { withholding tax rate was } 10 \text { percent on all maturities, } \\
\text { but Finance Minister Mehmet Simsek said the rate on } \\
\text { bonds with maturity over five years would be zero, and } \\
5 \text { percent on bonds of between three and five years } \\
\text { maturity. The rate will stay at } 10 \text { percent on bonds with } \\
\text { a maturity of up to three years. }\end{array}$ \\
\hline Turkey & 2010 & I & $\mathrm{T}$ & CCOT & $\mathrm{F}$ & IT & $\mathrm{P}$ & $\mathrm{E}$ & $\begin{array}{l}\text { Details of previously announced withholding tax rates } \\
\text { on bonds issued abroad by Turkish firms are published } \\
\text { in the official gazette. On maturities of up to } 1 \text {-year tax, } \\
\text { tax of } 10 \text { percent will be applied. On } 1-3 \text { year } \\
\text { maturities, the tax is } 7 \text { percent, then } 3-5 \text { years } 3 \\
\text { percent, and longer than } 5 \text { years zero tax. }\end{array}$ \\
\hline Turkey & 2011 & & E & & $\mathrm{F}$ & IT & $\mathrm{P}$ & E & $\begin{array}{l}\text { Lira RRR further increased across maturities, ranging } \\
\text { from } 9 \text { percent for deposits with maturity of up to three } \\
\text { months and non-deposit liabilities to } 12 \text { percent for } \\
\text { demand deposits. RRR for longer term Lira and FX } \\
\text { deposits left unchanged }\end{array}$ \\
\hline
\end{tabular}

Source: IMF AREAER 2009, Reinhart and Reinhart (2008), various news items and other research papers

Note the following abbreviations used in Appendix Table 1:

I/O - Inflow/outflow; T/E - Tightening/easing; CC - Capital control (CCPT - capital control prudential type; CCOT - capital control other; CBPT - currency-based prudential type; CBOT - currency-based other; OMOT - others); XR - IMF classification of exchange rate arrangement as of Apr-09 (SP - soft peg; F - floating; FF - free float); MP - IMF classifications, as of April 2009, of monetary policy arrangements as of Apr-09 (XA - exchange rate anchor, associated with hard or soft pegs; IT inflation targeting; $\mathrm{O}$ - other; blank - no explicitly stated nominal anchor); M/P/Q - Monitoring/Price/Quantitative; R - Region (A - Asia; Af - Africa; E - Europe; LA - Latin America) 


\section{A.3. The analytical distinctions between Capital Controls, Capital Flow Measures and Macro-prudential measures.}

Since capital inflow surges to developing economies are often followed by sudden stops, and many of these countries are still unable to borrow abroad in their own currencies (leading to currency mismatches and foreign currency liquidity risk), such surges can give rise to macrostability concerns. ${ }^{23}$ A growing number of EME policymakers argue that capital controls, and more broadly, measures to manage capital flows, are macroprudential in nature - that they are can be useful in preventing the build-up of risks and for reducing the damage associated with sudden stops. ${ }^{24}$ This section attempts to clarify the analytical distinction between macroprudential measures, capital flow management measures, and capital controls.

\section{What are macroprudential measures?}

Although the definition of "macroprudential measures" is still evolving, the term is used to denote any measure that aims to address two key concerns: ${ }^{25}$

a) the pro-cyclicality of finance, i.e., the existence of mechanisms through which financial system can amplify the business cycle; and

b) the stability of the financial sector as a whole, rather than individual institutions.

Macroprudential policy is therefore "defined by reference to an objective (limiting systemic or system-wide financial risk), the scope of analysis (the financial system as a whole and its interactions with the real economy), a set of instruments and their governance (prudential tools and those specifically assigned to macroprudential authorities.)".${ }^{26}$ Macroprudential measures typically work through the regulated financial sector.

\section{What are capital flow management measures (CFMs)?}

As defined in this paper, the instruments that may be used for capital flow management include:

i. Residency-based CFMs, more commonly referred to as capital controls. These are rules and regulations on the capital account that discriminate between residents and nonresidents.

ii. Other CFMs, which do not discriminate on the basis of residency but which are designed to influence inflows. These include measures that differentiate transactions based on currency (e.g.: limits on foreign currency borrowings, currency specific reserve requirements). This category may include some prudential measures.

\footnotetext{
${ }^{23}$ For countries like Brazil which are able to borrow in their own currency, this risk is mitigated.

${ }^{24}$ South Korea's "President Lee Myung-Bak, in an interview with the Financial Times published on Oct. 29, said any measures that the country may take to smooth cross-border capital flows should not be interpreted as capital controls but 'macroprudential policies'." Factbox - South Korean Policymakers' remarks on capital controls, Reuters, 12 November, 2010.

${ }^{25}$ BIS (2008) "Addressing financial system pro-cyclicality: a possible framework", Note for the FSF Working Group on Market and Institutional Resilience.

${ }^{26}$ BIS, FSB and IMF (2011), "Macroprudential policy tools and frameworks: Update to the G-20 Finance Ministers and Governors".
} 
A recent IMF paper on managing capital controls defines capital flow management measures as all measures imposed with the objective of influencing capital flows. ${ }^{27}$ Analogous to macroprudential measures, CFMs are also defined with respect to an objective, in this case, influencing capital inflows. As the IMF document notes, the classification of a particular measure as CFM requires exercise of judgement as to whether the measure was designed to influence capital flows. Thus defined, CFMs would include both types of measures mentioned above, but in addition may include other measures, for example those applied in the nonfinancial sector (e.g. minimum holding period for certain instruments, taxes on some investments), as long as the objective of such measures is to influence capital flows.

\section{Understanding capital controls}

Capital controls are not defined with respect to an objective, although typically they have been used to stem capital inflows. They are a particular type of policy instrument - all rules or regulations that apply to transactions on the capital account and that discriminate between the residents of the economy and non-residents, are considered capital controls. They are instruments that are defined only on the basis of whether they create an uneven playing field between residents and non-residents. This implies that not all regulations relating to capital account transactions, even those imposed with the same objective are capital controls. When a government imposes a rule or restriction on transactions on the capital account that applies equally to domestic and foreign residents -for example, a higher reserve requirement on foreign currency deposits - this is not considered a capital control. However, if the reserve requirements on deposits from foreigners were set to be higher than those on deposits from domestic residents, that would be a capital control. Note that this distinction does not depend on the objective for which the instrument was used.

\section{Under what circumstances can capital controls be considered instruments of macroprudential policy?}

Capital controls can be considered macroprudential when they are applied with the objective of addressing (and targeting) systemic risk, and when they are underpinned by governance arrangements that ensure no slippage in their use. ${ }^{28}$ Capital controls or other measures imposed with the objective of reducing capital inflows are not necessarily macroprudential.

A useful way of thinking about the distinction is to consider macroprudential policy with respect to the domestic financial sector. When domestic credit expansion is 'excessive', macroprudential authorities may take steps to dampen credit expansion, but would also take steps to tackle specific risks building in the system, or to create capital buffers to help cushion the impact of a downturn. ${ }^{29}$ In the context of capital flows, macroprudential policy - in the face of excessive

\footnotetext{
27 "Recent Experiences in Managing Capital Inflows: Cross-Cutting Themes and Possible Framework", IMF (2011)

${ }^{28}$ BIS, FSB and IMF (2011), "Macroprudential policy tools and frameworks: Update to the G-20 Finance Ministers and Governors".

${ }^{29}$ The analytical framework for macroprudential policy is still evolving and while tools to restrict credit expansion (e.g. marginal reserves requirements on banks) are not typically prudential in nature, they have been used in a number of countries in a counter-cyclical fashion and are considered by regulators to be "macroprudential". See, BIS, FSB and IMF (2011), "Macroprudential policy tools and frameworks: Update to the G-20 Finance Ministers
} 
inflows leading to overheating of the domestic economy - may consist of instruments to dampen the size of the net inflows ${ }^{30}$ as well as measures to address specific risks ${ }^{31}$ and to create capital buffers $^{32}$. In addition, prudential tools like variable LTV ratios, counter-cyclical capital buffers, etc. can help mitigate excessive build-up of credit or asset bubbles related to inflow surges, without targeting inflows directly.

To summarize, measures to limit capital inflows, whether or not they discriminate by residency, may be considered appropriate instruments from a macroprudential perspective, if they are imposed with the objective of maintaining macro-financial stability (rather than with the objective of preventing exchange rate appreciation) and if they are accompanied by appropriate governance arrangements that prevent slippage in their use. These conditions are more likely to be met when capital controls regulations are recommended by a macroprudential supervisory body, free of political interference.

\section{A.4. Data Appendix}

Table A.3: Countries included in the analysis

\begin{tabular}{|lllll|}
\hline Argentina & Czech Republic & Korea & Philippines & Thailand \\
Brazil & Egypt & Malaysia & Poland & Turkey \\
Chile & Hungary & Mexico & Russia & \\
China & India & Morocco & South Africa & \\
Colombia & Indonesia & Peru & Taiwan & \\
\hline
\end{tabular}

Table A.4: Variable Descriptions

\begin{tabular}{|c|c|c|}
\hline Variable & Source & Description \\
\hline $\begin{array}{l}\text { Bank } \\
\text { Credit }\end{array}$ & $I F S, W D I$ & $\begin{array}{l}\text { Domestic credit provided by the banking sector as a percentage of GDP. For } \\
\text { Argentina, China, India and Korea, } 2010 \text { values are calculated by applying the } \\
\text { growth rates of the Claims on Private Sector series under Deposit Money } \\
\text { Bank/Other Depository Corporations sections from IMF's International Financial } \\
\text { Statistics (IFS) database to Bank Credit for } 2009 \text {. For these countries, } 2010 \text { bank } \\
\text { credit is calculated as BankCredit as } \% \text { of } \mathrm{GDP}_{2009}{ }^{*}\left(\mathrm{Claims}_{2010} / \mathrm{Claims}{ }_{2009} \text { ). All }\right. \\
\text { other data are obtained from the World Development Indicators (WDI) database. }\end{array}$ \\
\hline $\begin{array}{l}\text { Capital } \\
\text { Account } \\
\text { Balance }\end{array}$ & $\begin{array}{l}\text { IFS, China } \\
\text { Statistics } \\
\text { Information \& } \\
\text { Service Centre }\end{array}$ & $\begin{array}{l}\text { Capital account, n.i.e.. For Brazil, Czech Republic, Hungary, Peru and Philippines, } \\
\text { annual estimates for } 2010 \text { are calculated from available quarterly data. With two } \\
\text { quarters of data available, annual estimates are calculated as }(\mathrm{Q} 1+\mathrm{Q} 2)^{*} 2 \text {. With } \\
\text { three quarters of data available, annual estimates are calculated as } \\
(\mathrm{Q} 1+\mathrm{Q} 2+\mathrm{Q} 3)^{*} 4 / 3 \text {. } 2010 \text { data for China is obtained from the China Statistics } \\
\text { Information \& Service Centre. All other series are obtained from IFS. }\end{array}$ \\
\hline $\begin{array}{l}\text { Chinn-Ito } \\
\text { Index }\end{array}$ & & $\begin{array}{l}\text { A de-jure measure of financial openness. The index is currently updated to } 2009 \\
\text { and can be obtained from Menzie Chinn or Hiro Ito's homepages. }\end{array}$ \\
\hline
\end{tabular}

and Governors" and IMF (2011) "Macroprudential policy -an organizing framework - background paper", March 2011.

${ }^{30} \mathrm{CFMs}$ like tax on inflows, limits on foreign currency borrowing or other measures, including capital controls.

${ }^{31}$ Examples include limits on currency mismatches, open derivative positions, short term borrowing limits, limits on foreign currency leverage ratios, etc

${ }^{32}$ For example, higher reserve ratios for foreign currency deposits. 


\begin{tabular}{|c|c|c|}
\hline Variable & Source & Description \\
\hline $\begin{array}{l}\text { Current } \\
\text { Account } \\
\text { Balance }\end{array}$ & $I F S, W E O$ & $\begin{array}{l}\text { Current account balance, n.i.e.; negatives values indicate deficits. } 2011 \text { forecast } \\
\text { values for all countries are obtained from the April } 2011 \text { WEO. For Argentina, } \\
\text { Brazil, Colombia, Czech Republic and Morocco, } 2010 \text { values are also obtained } \\
\text { from the WEO. All other data are obtained from IFS. }\end{array}$ \\
\hline $\begin{array}{l}\text { Financial } \\
\text { Account } \\
\text { Balance }\end{array}$ & $\begin{array}{l}\text { IFS, China } \\
\text { Statistics } \\
\text { Information \& } \\
\text { Service Centre }\end{array}$ & $\begin{array}{l}\text { Financial account, n.i.e.; negative values indicate deficits. For Brazil, Czech } \\
\text { Republic, Hungary, Peru and Philippines, annual estimates for } 2010 \text { are calculated } \\
\text { from available quarterly data. With two quarters of data available, annual estimates } \\
\text { as calculated as (Q1+Q2)*2. With three quarters of data available, annual estimates } \\
\text { are calculated as (Q1+Q2+Q3)*4/3. } 2010 \text { data for China is obtained from the China } \\
\text { Statistics Information \& Service Centre. All other series are obtained from IFS. }\end{array}$ \\
\hline GDP & $W D I$ & Gross domestic product in current US dollars. \\
\hline Inflation & $\begin{array}{l}\text { IFS, WEO \& } \\
\text { Author's } \\
\text { calculations }\end{array}$ & $\begin{array}{l}\text { Calculated from annual consumer price index series (CPI) using } 2005 \text { as base year. } \\
\text { CPI data for China, Taiwan, Chile and } 2011 \text { forecasts are obtained from the April } \\
2011 \text { World Economic Outlook (WEO) database. All other CPI data are obtained } \\
\text { from IFS. }\end{array}$ \\
\hline $\begin{array}{l}\text { Net Capital } \\
\text { Inflows }\end{array}$ & $\begin{array}{l}\text { IFS, China } \\
\text { Stat Info \& } \\
\text { Service Centre } \\
\& \text { Author's } \\
\text { calculations }\end{array}$ & $\begin{array}{l}\text { The net capital inflows series is calculated as the sum of capital account balance } \\
\text { and financial account balance. When capital account balance is absent, for example } \\
\text { in the case of India, net capital inflows is equal to financial account balance. }\end{array}$ \\
\hline $\begin{array}{l}\text { Net Private } \\
\text { Capital } \\
\text { Inflows }\end{array}$ & IIF & $\begin{array}{l}\text { IIF's new measure of net private capital inflows to emerging market economies } \\
\text { (EMEs) is used. In addition to the } 21 \text { countries (Taiwan excluded) used in the GIR, } \\
\text { IIF's group of EMEs also includes Bulgaria, Romania, Ukraine, Ecuador, } \\
\text { Venezuela, Lebanon, Nigeria, Saudi Arabia and UAE. }\end{array}$ \\
\hline Reserves & IFS & Foreign exchange reserves less gold. \\
\hline $\begin{array}{l}\text { Short Term } \\
\text { External } \\
\text { Debt }\end{array}$ & WDI, IIF & $\begin{array}{l}\text { External debt stocks, short term. Data for Czech Republic, Hungary, Korea and } \\
\text { Poland are obtained from the Institute of International Finance (IIF). For all other } \\
\text { countries, } 2010 \text { values are calculated using the year on year growth rate from } 2009 \\
\text { to } 2010 \text { of the Short Term Debt, External Debt and Assets series (D203) from IIF } \\
\text { as ShorTermExternalDebt }{ }_{2009} *\left(\mathrm{D} 203_{2010} / \mathrm{D} 203_{2009}\right) \text {. All other series are obtained } \\
\text { from the World Bank's World Development Indicators database. }\end{array}$ \\
\hline $\begin{array}{l}\text { Under- } \\
\text { valuation } \\
\text { using PPP } \\
\text { measures }\end{array}$ & $\begin{array}{l}\text { Penn World } \\
\text { Table } 7.0 \& \\
\text { Author's } \\
\text { calculations }\end{array}$ & $\begin{array}{l}\text { Two series were used to compute this series. PPP real exchange rate is the } \\
\text { Purchasing Power Parity over GDP in national currency units per US dollar. GDP } \\
\text { per capita is PPP converted GDP per capita at } 2005 \text { constant prices (International } \\
\text { dollar per person). Both series are obtained from Penn World Table } 7.0 \text {. }\end{array}$ \\
\hline
\end{tabular}

Recent trends in measures to manage capital flows in emerging economies 